Article

\title{
Stereoselective Alkane Oxidation with meta-Chloroperoxybenzoic Acid (MCPBA) Catalyzed by Organometallic Cobalt Complexes ${ }^{\dagger}$
}

\author{
Georgiy B. Shul'pin ${ }^{1,2}, *$, Dmitriy A. Loginov ${ }^{3}$, Lidia S. Shul' pina $^{3}{ }^{3}$ Nikolay S. Ikonnikov $^{3}$, \\ Vladislav O. Idrisov ${ }^{3}$, Mikhail M. Vinogradov ${ }^{3}$, Sergey N. Osipov ${ }^{3}$, Yulia V. Nelyubina ${ }^{3}$ and \\ Polina M. Tyubaeva ${ }^{2}$
}

1 Semenov Institute of Chemical Physics, Russian Academy of Sciences, ulitsa Kosygina, dom 4, Moscow 119991, Russia

2 Chair of Chemistry and Physics, Plekhanov Russian University of Economics, Stremyannyi pereulok, dom 36, Moscow 117997, Russia; popov.AnA@rea.ru

3 Nesmeyanov Institute of Organoelement Compounds, Russian Academy of Sciences, ulitsaVavilova, dom 28, Moscow 119991, Russia; dloginov@ineos.ac.ru (D.A.L.); shulpina@ineos.ac.ru (L.S.S.); ikonns@ineos.ac.ru (N.S.I.); vladchem32@gmail.com (V.O.I.); mmvngrdv@gmail.com (M.M.V.); osipov@ineos.ac.ru (S.N.O.); unelya@xrlab.ineos.ac.ru (Y.V.N.)

* Correspondence: shulpin@chph.ras.ru; Tel.: +7-495-939-7317; Fax: +7-495-651-2191

+ This work was partly presented at the 16th International Congress on Catalysis, Beijing, China, 2016, lecture OF24.

Academic Editor: Derek J. McPhee

Received: 23 October 2016; Accepted: 16 November 2016; Published: 22 November 2016

\begin{abstract}
Cobalt pi-complexes, previously described in the literature and specially synthesized and characterized in this work, were used as catalysts in homogeneous oxidation of organic compounds with peroxides. These complexes contain pi-butadienyl and pi-cyclopentadienyl ligands: [(tetramethylcyclobutadiene)(benzene)cobalt] hexafluorophosphate, $\left[\left(\mathrm{C}_{4} \mathrm{Me}_{4}\right) \mathrm{Co}\left(\mathrm{C}_{6} \mathrm{H}_{6}\right)\right] \mathrm{PF}_{6}$ (1); diiodo(carbonyl)(pentamethylcyclopentadienyl)cobalt, $\mathrm{Cp}^{*} \mathrm{Co}(\mathrm{CO}) \mathrm{I}_{2}$ (2); diiodo(carbonyl)

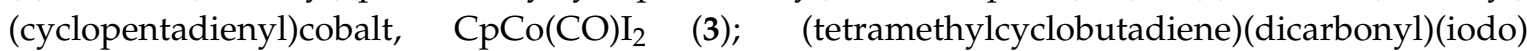
cobalt, $\left(\mathrm{C}_{4} \mathrm{Me}_{4}\right) \mathrm{Co}(\mathrm{CO})_{2} \mathrm{I} \quad(4) ; \quad$ [(tetramethylcyclobutadiene)(acetonitrile)(2,2'-bipyridyl)cobalt] hexafluorophosphate, $\left[\left(\mathrm{C}_{4} \mathrm{Me}_{4}\right) \mathrm{Co}(\right.$ bipy $\left.)(\mathrm{MeCN})\right] \mathrm{PF}_{6}$ (5); bis[dicarbonyl(B-cyclohexylborole)]cobalt, $\left[\left(\mathrm{C}_{4} \mathrm{H}_{4} \mathrm{BCy}\right) \mathrm{Co}(\mathrm{CO})_{2}\right]_{2} \quad$ (6); [(pentamethylcyclopentadienyl)(iodo)(1,10-phenanthroline)cobalt $]$ hexafluorophosphate, $\left[\mathrm{Cp}^{*} \mathrm{Co}(\mathrm{phen}) \mathrm{I}_{\mathrm{PF}} \mathrm{F}_{6}(7) ;\right.$ diiodo(cyclopentadienyl)cobalt, $\left[\mathrm{CpCoI}_{2}\right]_{2}$ (8); [(cyclopentadienyl)(iodo)(2,2'-bipyridyl)cobalt] hexafluorophosphate, [CpCo(bipy)I] $\mathrm{PF}_{6}$ (9); and [(pentamethylcyclopentadienyl)(iodo)(2,2'-bipyridyl)cobalt] hexafluorophosphate, $\left[\mathrm{Cp}{ }^{*} \mathrm{Co}(\right.$ bipy)I $] \mathrm{PF}_{6}(\mathbf{1 0})$. Complexes 1 and $\mathbf{2}$ catalyze very efficient and stereoselective oxygenation of tertiary $\mathrm{C}-\mathrm{H}$ bonds in isomeric dimethylcyclohexanes with MCBA: cyclohexanols are produced in 39 and $53 \%$ yields and with the trans/cis ratio (of isomers with mutual trans- or cis-configuration of two methyl groups) 0.05 and 0.06 , respectively. Addition of nitric acid as co-catalyst dramatically enhances both the yield of oxygenates and stereoselectivity parameter. In contrast to compounds $\mathbf{1}$ and 2, complexes $\mathbf{9}$ and $\mathbf{1 0}$ turned out to be very poor catalysts (the yields of oxygenates in the reaction with cis-1,2-dimethylcyclohexane were only $5 \%-7 \%$ and trans/cis ratio 0.8 indicated that the oxidation is not stereoselective). The chromatograms of the reaction mixture obtained before and after reduction with $\mathrm{PPh}_{3}$ are very similar, which testifies that alkyl hydroperoxides are not formed in this oxidation. It can be thus concluded that the interaction of the alkanes with MCPBA occurs without the formation of free radicals. The complexes catalyze oxidation of alcohols with tert-butylhydroperoxide (TBHP). For example, tert-BuOOH efficiently oxidizes 1-phenylethanol to acetophenone in $98 \%$ yield if compound $\mathbf{1}$ is used as a catalyst.
\end{abstract}


Keywords: alkanes; alcohols; metal complexes; X-ray analysis; meta-chloroperoxybenzoic acid (MCPBA); stereoselective oxidation

\section{Introduction}

Selective functionalization of $\mathrm{C}-\mathrm{H}$ bonds in hydrocarbons and other compounds is a very real aim of contemporary catalytic science [1-4]. Numerous transition metal complexes play roles of efficient catalysts in oxygenation of hydrocarbons as well as alcohols [5-14]. Derivatives of cobalt are known to catalyze various transformations of organic compounds [15-24]. Molecular oxygen, hydrogen peroxide, tert-butyl hydroperoxides, and peroxyacids were used as oxidants in these oxygenations. Certain complexes of transition metals have been previously reported to oxidize organic compounds including alkanes with meta-chloroperoxybenzoicacid (MCPBA [25]) [25-44] (see, for example, complexes of cobalt [21,24,38], manganese [26,27,34,36,44], iron [28], nickel [30-33,35,37,39,42,43] and vanadium [40]). Earlier, Nam [15,16] reported that alkane oxidation with MCPBA catalyzed by some cobalt compounds proceeds stereoselectively. It is interesting to check the oxidation various cobalt organometallic complexes bearing ligands of different types, $\pi$-cyclobutadienyl, cyclopentadienyl, $\pi$-arene, carbonyl, amine, etc. derivatives, and compare both their activity in the reaction and stereoselectivity. It is also attractive to find any dependence of the product yield and stereoselectivity parameter on the structure of the particular complex. Complexes containing various ligands in different compositions have been chosen.

In the present work, we studied oxidation of alkanes and alcohols with peroxides catalyzed by certain organometallic derivatives of cobalt. Many of the complexes have been synthesized and characterized in this work for the first time.

\section{Results and Discussion}

\subsection{Catalysts, Substrates and Oxidants}

We used various cyclobutadienyl and cyclopentadienyl derivatives of cobalt as catalysts for oxidation of organic compounds with peroxides. Structural formulae of the catalysts are depicted in Scheme 1.

\subsection{Syntheses of Catalysts}

Syntheses of new complexes obtained in this work are described in Section 3.2. Complex $\left[\mathrm{CpCo}(\right.$ bipy)I] $] \mathrm{PF}_{6}$ (9) was prepared in high yield by the described in the literature method but with the usage of the improved counterion-exchange procedure (see Section 3.2). The related pentamethylated complexes with $\mathrm{N}$,N-ligands, $\left[\mathrm{Cp}^{*} \mathrm{Co}(\mathrm{phen}) \mathrm{I}\right] \mathrm{PF}_{6}(7)$ and $\left[\mathrm{Cp}^{*} \mathrm{Co}\left(\right.\right.$ bipy)I] $\mathrm{PF}_{6}(\mathbf{1 0})$, were synthesized in similar way by reactions of $\mathrm{Cp}^{*} \mathrm{Co}(\mathrm{CO}) \mathrm{I}_{2}$ (2) with 1,10-phenanthroline and 2,2'-bipyridyl. The cyclobutadiene complex $\left[\left(\mathrm{C}_{4} \mathrm{Me}_{4}\right) \mathrm{Co}\right.$ (bipy) $\left.(\mathrm{MeCN})\right] \mathrm{PF}_{6}(5)$ was prepared by photochemical replacement of benzene ligand in $\left[\left(\mathrm{C}_{4} \mathrm{Me}_{4}\right) \mathrm{Co}\left(\mathrm{C}_{6} \mathrm{H}_{6}\right)\right] \mathrm{PF}_{6}(\mathbf{1})$ by 2,2'-bipyridyl in acetonitrile solution. All cationic complexes described here were isolated as salts with the $\mathrm{PF}_{6}{ }^{-}$anion. All catalysts are indefinitely stable in air in solid state.

\subsection{Structures of Catalysts}

Complexes 7, 9, and 10 were investigated by X-ray diffraction. Their molecular structures, bond lengths and angles as well as crystallographic data and structure refinement parameters are given in Figures $1-3$ as well as in Section 3.3.

In the case of 9 , the symmetry-independent part of the unit cell contains two formula units. All complexes have a piano-stool geometry. The bi-pyridine ligand in $\mathbf{9}$ and $\mathbf{1 0}$ is almost planar; the dihedral angle formed by the intersection of the planes defined by the pyridyl rings is equal to 
5.83 (6.55) and $8.78^{\circ}$, respectively. The Co $\cdots C_{5}$ distance in pentamethylated complexes 10 (1.691 $\AA$ ) and 7 (1.687 $\AA$ ) is somewhat longer than the corresponding distance in the unsubstituted derivative 1 (1.667 and $1.683 \AA$, average $1.675 \AA$ ); this can be explained by sterical effect of five methyl groups. The length of the Co-I bond in the three complexes 7, 9 and 10 varies in the range 2.5718(13)-2.5798(4) $\AA$.

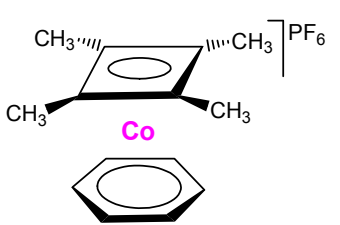

1

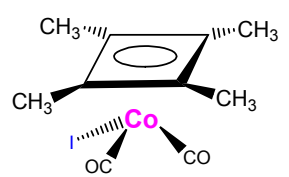

4

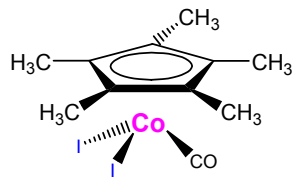

2

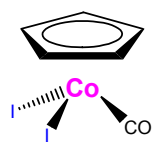

3

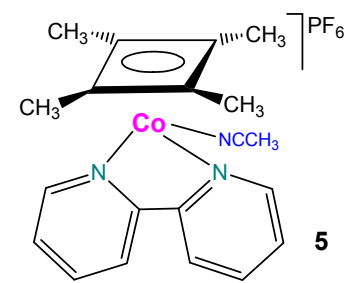

5

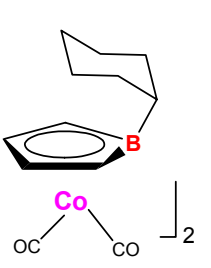

6

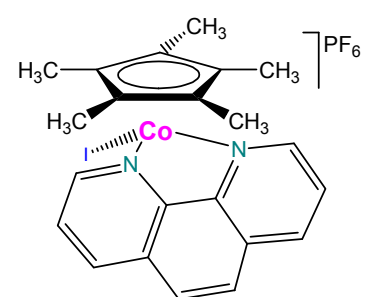

7

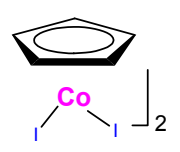

8<smiles></smiles>

9

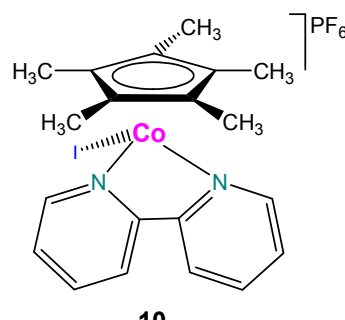

10

Scheme 1. Structural formulae of the catalysts used in this work.

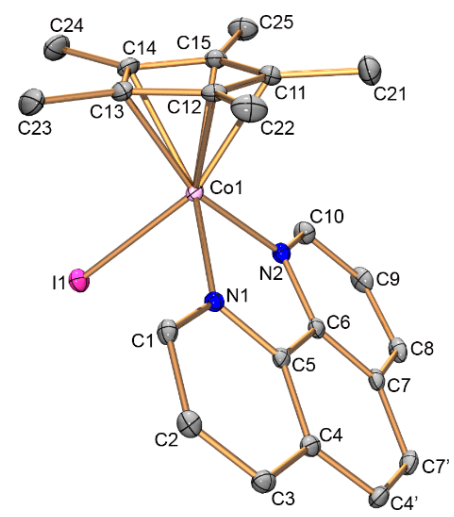

Figure 1. Structure of cation $\left[\mathrm{Cp}^{*} \mathrm{Co}(\mathrm{phen}) \mathrm{I}\right]^{-}$(7). Atoms are represented by $50 \%$ thermal ellipsoids. Hydrogen atoms are omitted for clarity. Selected bond lengths $[\AA]$ and angles $\left[{ }^{\circ}\right]$ : Co1-C11 2.059(3), Co1-C12 2.079(3), Co1-C13 2.061(3), Co1-C14 2.099(3), Co1-C15 2.097(3), Co1-N1 1.958(2), Co1-N2 1.968(2), Co1-I1 2.5798(4), and N1-Co1-N2 82.85(9). 


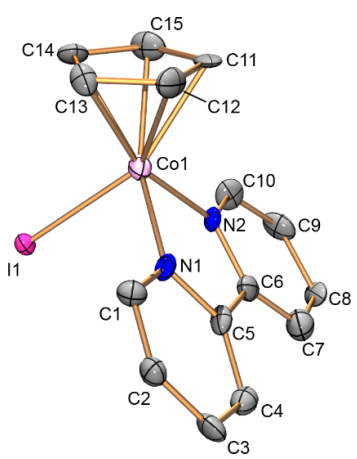

Figure 2. Structure of cation $\left[\mathrm{CpCo}(\text { bipy)I }]^{-}\right.$(9). Atoms are represented by $50 \%$ thermal ellipsoids. Hydrogen atoms are omitted for clarity. Selected bond lengths $[\AA]$ and angles $\left[{ }^{\circ}\right]$ for the first/second symmetry-independent species: Co1-C11 2.046(17)/2.049(17), Co1-C12 2.06(2)/2.050(16), Co1—C13 2.056(17)/2.063(17), Co1—C14 2.127(17)/2.061(16), Co1—C15 2.072(19)/2.045(17), Co1—N1 1.932(14)/1.936(15), Co1-N2 1.966(13)/1.956(17), Co1-I1 2.574(3)/2.575(2), and N1-Co1-N2 $82.2(5) / 82.7(6)$.

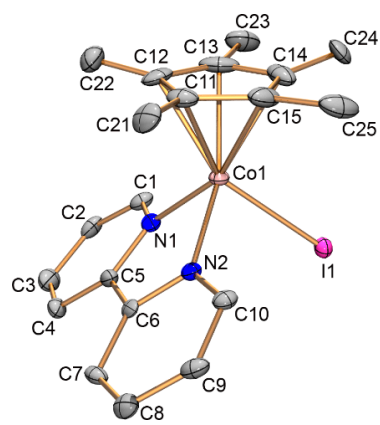

Figure 3. Structure of cation $\left[\mathrm{Cp} \mathrm{P}^{*} \mathrm{Co}(\text { bipy })\right]^{-}(\mathbf{1 0})$. Atoms are represented by $50 \%$ thermal ellipsoids. Hydrogen atoms are omitted for clarity. Selected bond lengths $[\AA]$ and angles $\left[{ }^{\circ}\right]$ : Co1-C11 2.048(10), Co1-C12 2.066(10), Co1-C13 2.074(12), Co1—C14 2.095(10), Co1-C15 2.065(11), Co1—N1 1.965(8), Co1-N2 1.954(8), Co1-I1 2.5718(13), and N1-Co1-N2 81.6(3).

The main geometric parameters of $\mathbf{1 0}$ resembles those in a recently characterized chloride analog $\left[\mathrm{Cp}{ }^{*} \mathrm{Co}\right.$ (bipy) $\mathrm{Cl}_{\mathrm{PF}_{6}}$ [45]. For example, the dihedral angle between the $\mathrm{Cp}$ and bipy planes in $10\left(38.2^{\circ}\right)$ is close to that in $\left[\mathrm{Cp}^{*} \mathrm{Co}(\right.$ bipy $) \mathrm{Cl} \mathrm{PF}_{6}\left(41.5^{\circ}\right)$ but smaller than in $9\left(\right.$ average $\left.50.1^{\circ}\right)$ and $7\left(49.2^{\circ}\right)$.

\subsection{Determination of Alkyl Hydroperoxides by GC before and after Reduction with $\mathrm{PPh}_{3}$}

Earlier, one of us developed a convenient method for the analysis of mixtures obtained in alkane oxidation with molecular oxygen or peroxides [46-55] (the Shul'pin method [56]). In many cases, oxidation leads to the formation of three main products (alkyl hydroperoxide, alcohol and ketone). If a reaction solution is injected directly (see, for example, [57-62]) to the chromatograph, the alkyl hydroperoxide $\mathrm{ROOH}$ (if present) decomposes in the injector and/or column to produce the alcohol and ketone in approximately equal amounts.

However, if a sample of the reaction mixture is reduced by an excess of solid $\mathrm{PPh}_{3}$ (or thiourea) during 10-20 $\mathrm{min}$, the alkyl hydroperoxide is quantitatively transformed into the corresponding alcohol. Comparing concentrations of the alcohol and ketone before and after treatment with $\mathrm{PPh}_{3}$, we can qualitatively conclude on existence or non-existence of $\mathrm{ROOH}$ in the solution [63-71]. Moreover, the real concentrations of the alkyl hydroperoxide as well as of alcohol and ketone can be calculated (estimated) using the data obtained before and after reduction [72-81]. Selectivity of the oxidation reaction can be characterized by the parameter $[\mathrm{ROOH}+\mathrm{A}] /[\mathrm{K}]$ where $[\mathrm{ROOH}+\mathrm{A}]$ and $[\mathrm{K}]$ are 
concentrations of alcohol and ketone after reduction with $\mathrm{PPh}_{3}$, respectively [82,83]. However, this parameter gives us absolutely no information on existence or non-existence of $\mathrm{ROOH}$ in the solution.

We must emphasize that, although treatment with $\mathrm{PPh}_{3}$ can be used in order to only remove from the reaction mixtures peroxides (starting $\mathrm{H}_{2} \mathrm{O}_{2}$, tert- $\mathrm{BuOOH}$, produced $\mathrm{ROOH}$ etc.) [84-91], the main aim of the method under discussion is estimation of real concentrations of $\mathrm{ROOH}$, alcohol and ketone formed in the reaction. Chromatograms obtained only after reduction of the reaction mixture cannot be used for determination of real concentration of each oxygenate. Nevertheless, such chromatograms give valuable information on the total concentration of produced oxygenates.

\subsection{Oxidation of Alkanes and Alcohols with Peroxides}

We have tested the catalytic effect of compound 1-10 in the reactions of alkanes and alcohols with various oxidants. These reactions are summarized in Scheme 2.

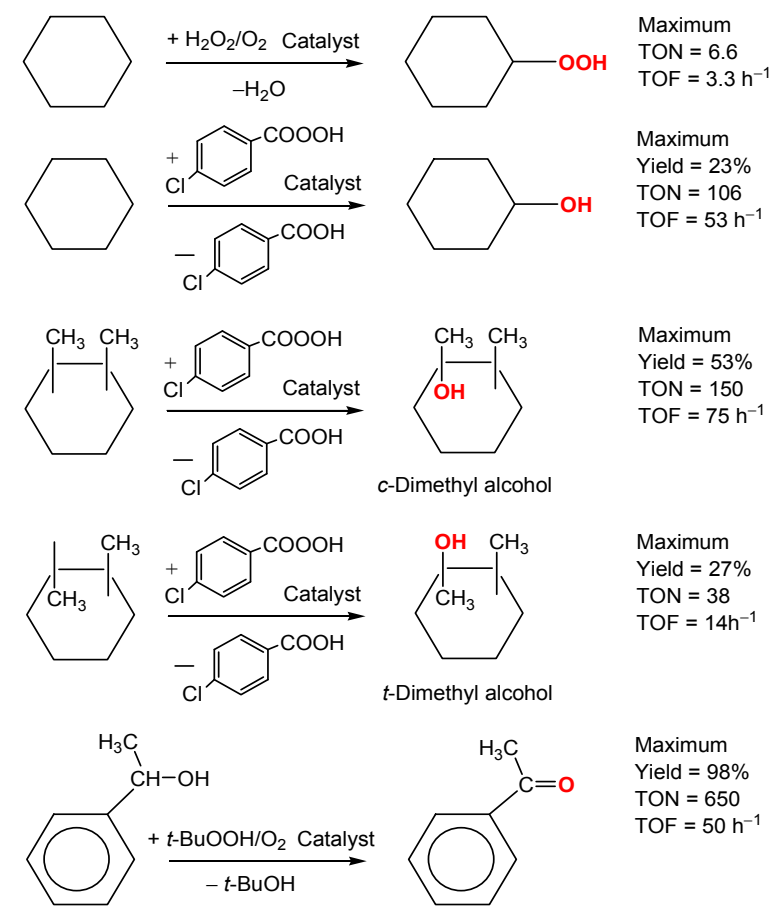

Scheme 2. Examples of oxidation reactions studied in this work.

All complexes exhibited low activity in the oxidations with hydrogen peroxide. Some examples are presented in Table 1. The oxidation affords predominantly cyclohexyl hydroperoxide because the treatment of the reaction solution with $\mathrm{PPh}_{3}$ leads to the decrease of the ketone peak and increase of the alcohol peak in GC [55] (compare entries 1 and 2 in Table 1).

Table 1. Oxidation of cyclohexane with hydrogen peroxide catalyzed by cobalt complexes ${ }^{1}$.

\begin{tabular}{|c|c|c|c|c|c|c|c|}
\hline Entry & Cat & Time (min) & Reduction with $\mathrm{PPh}_{3}$ & Cyclohexanone (mM) & Cyclohexanol (mM) & TON & TOF $\left(h^{-1}\right)$ \\
\hline 1 & 1 & 30 & No & 0.05 & 0.07 & 0.24 & 0.48 \\
\hline 2 & & 30 & Yes & 0 & 0.3 & 0.6 & 1.2 \\
\hline 3 & & 120 & No & 0.05 & 0.08 & & \\
\hline 4 & & 120 & Yes & 0 & 0.7 & & \\
\hline 5 & $5^{2}$ & 60 & Yes & 0.1 & 0.6 & & \\
\hline 6 & & 180 & Yes & 0.5 & 1.0 & & \\
\hline 7 & 7 & 120 & Yes & 0 & 1.4 & & \\
\hline 8 & $7^{2}$ & 60 & Yes & 0.2 & 1.0 & & \\
\hline 9 & & 120 & Yes & 1.0 & 2.3 & 6.6 & 3.3 \\
\hline
\end{tabular}

${ }^{1}$ Conditions. Concentrations $[\text { Cat }]_{0}=5 \times 10^{-4} \mathrm{M}$, [cyclohexane $]_{0}=0.46 \mathrm{M},\left[\mathrm{H}_{2} \mathrm{O}_{2}\right]_{0}=1.5 \mathrm{M}, 50{ }^{\circ} \mathrm{C}$. Solvent $\mathrm{MeCN}$, total volume of the reaction solution was $5 \mathrm{~mL} ;{ }^{2}$ Nitric acid $(0.05 \mathrm{M})$ was added. 
Hydrogen peroxide is not a good oxidizing agent for alcohols in our case of cobalt catalysts. For example, 1-phenylethanol $\left(0.33 \mathrm{M}\right.$ ) after $180 \mathrm{~min}$ at $60{ }^{\circ} \mathrm{C}$ (other conditions are the same as in Table 1) gave $5.0 \mathrm{mM}$ of acetophenone (yield was only $1.5 \%$ ) when the reaction was catalyzed by complex 1. In contrast, tert-BuOOH efficiently oxidizes (yield $98 \%$ after $13 \mathrm{~h}$ ) 1-phenylethanol if compound $\mathbf{1}$ is used as a catalyst (Figure 4).
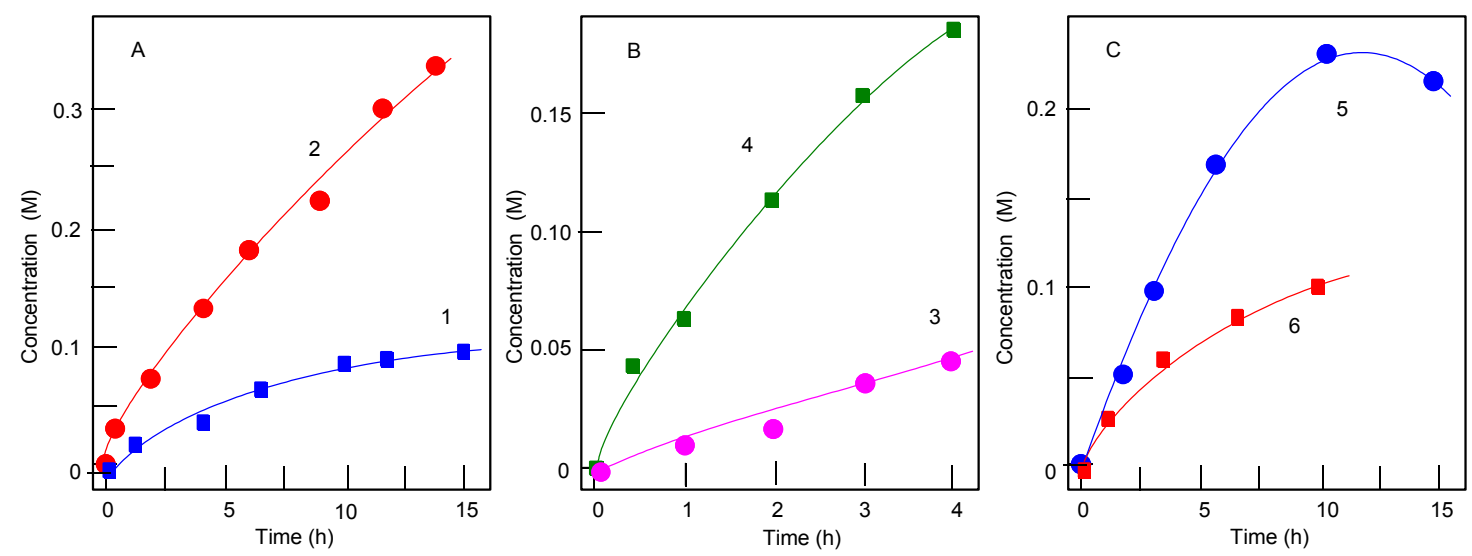

Figure 4. The 1-phenylethanol $(0.33 \mathrm{M})$ oxidation with tert-butyl hydroperoxide (TBHP; $70 \%$, aqueous, $1.65 \mathrm{M})$ : (A) Accumulation of acetophenone with time in in the absence (curve 1) and in the presence (curve 2 ) of compound $1\left(5 \times 10^{-4} \mathrm{M}\right)$. The reaction gave TON 650 and TOF $50 \mathrm{~h}^{-1}$. Temperature was $70{ }^{\circ} \mathrm{C}$, solvent was acetonitrile (total volume of the reaction solution was $5 \mathrm{~mL}$ ); (B) The same oxidation catalyzed by complex 4 at 50 (curve 3 ) and $70^{\circ} \mathrm{C}$ (curve 4 ); (C) The same oxidation $\left([\mathrm{TBHP}]_{0}=0.9 \mathrm{M}\right.$ ) catalyzed by complexes 9 (curve 5) and $\mathbf{1 0}$ (curve 6) at $70^{\circ} \mathrm{C}$.

\subsection{Stereoselective Oxidation with meta-Chloroperoxybenzoic Acid (MCPBA)}

It turned out that the third oxidant, MCPBA, is a weak oxidant in the reaction with 1-phenylethanol. Thus, the oxidation catalyzed by complex 1 in the presence of $\mathrm{HNO}_{3}$ (for the conditions, see Table 1 ) afforded after $3 \mathrm{~h}$ acetophenone in only $18 \%$ yield. The oxidation of cyclohexane was also inefficient (Table 2). It should be noted that the chromatogram made before and after reduction of samples with triphenylphosphine as well as the ketone/alcohol ratio is not changed in the chromatograms. This indicates that cyclohexyl hydroperoxide is not formed in the course of the oxidation (for this simple method, see References [46-56]). In contrast, Figure 5, which is presented here for comparison, demonstrates that cyclohexyl hydroperoxide, $\mathrm{CyOOH}$, is produced in the oxidation with MCPBA catalyzed by the salt $\mathrm{Mn}\left(\mathrm{ClO}_{4}\right)_{2}$. In the course of the reaction, $\mathrm{CyOOH}$ gradually decomposes to afford cyclohexanone and cyclohexanol.

Table 2. Oxidation of cyclohexane with meta-chloroperoxybeanzoic acid (MCPBA) catalyzed by cobalt complexes ${ }^{1}$.

\begin{tabular}{ccccccc}
\hline Entry & Cat & Time (min) & $\mathbf{H N O}_{3}(\mathbf{m M})$ & Cyclohexanone $(\mathbf{m M})$ & Cyclohexanol (mM) & Total Yield (\%) \\
\hline 1 & $\mathbf{1}$ & 120 & 50 & 18 & 5 & 16 \\
2 & $\mathbf{5}$ & 120 & 0 & 26 & 6 & 23 \\
3 & & 120 & 50 & 20 & 4.5 & 18 \\
4 & $\mathbf{6}$ & 60 & 50 & 0.7 & 2.6 & 3 \\
5 & & 180 & 50 & 1.9 & 5.3 & 5 \\
\hline
\end{tabular}

${ }^{1}$ Conditions. Concentrations [Cat $]_{0}=5 \times 10^{-4} \mathrm{M}$, [cyclohexane $]_{0}=0.23 \mathrm{M},[\mathrm{MCPBA}]_{0}=0.26 \mathrm{M}$. Solvent MeCN, total volume of the reaction solution was $5 \mathrm{~mL}$. For entry $2, \mathrm{TON}=106, \mathrm{TOF}=53 \mathrm{~h}^{-1}$. 


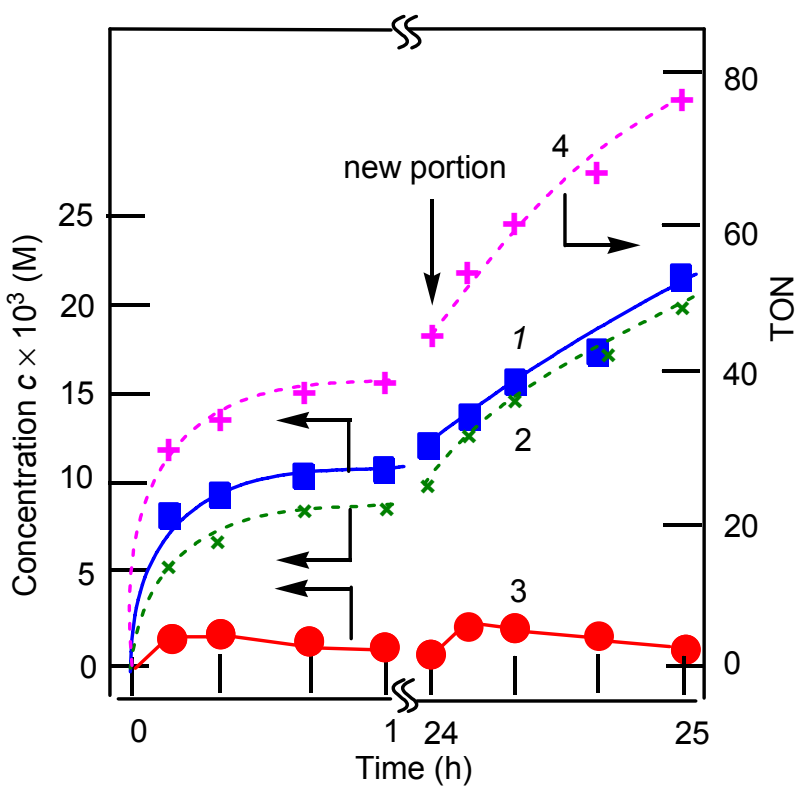

Figure 5. Accumulation of cyclohexanol (curve 1), cyclohexanone (curve 2), and cyclohexyl hydroperoxide (curve 3), as well as TON (curve 4 ) in the reaction of cyclohexane $(0.46 \mathrm{M})$ with MCPBA $(0.025 \mathrm{M})$ in $\mathrm{MeCN}$ at $25{ }^{\circ} \mathrm{C}$ catalyzed by $\mathrm{Mn}\left(\mathrm{ClO}_{4}\right)_{2}\left(5 \times 10^{-4} \mathrm{M}\right)$. Concentrations of cyclohexanone and cyclohexanol were measured by GC twice: before and after the reduction of the reaction mixture with $\mathrm{PPh}_{3}$ [46-56]. At the time moment denoted by an arrow, an additional amount $(0.025 \mathrm{M})$ of MCPBA was introduced into the reaction solution. After $25 \mathrm{~h}$, TON was 76, and the yield of all oxygenates based on MCPBA was $76 \%$.

The most impressive results have been obtained in oxidations of alkanes containing tertiary $\mathrm{C}-\mathrm{H}$ bonds. Thus, cobalt complexes under consideration exhibited relatively high activity in the oxidation of isomers of dimethylcyclohexane with MCPBA (Table 3). The chromatograms of the reaction solutions made before and after reduction of samples with triphenylphosphine are very similar (see Table 3 , run 6) and the ketone/alcohol ratio is not changed in the chromatograms. It should be noted that tertiary alkyl hydroperoxides easily decompose in hot injector with splitting $\mathrm{C}-\mathrm{H}$ bonds and formation of carbonyl derivatives [2]. If tertiary alkyl hydroperoxide is produced the chromatograms before and after reduction with $\mathrm{PPh}_{3}$ should be different which is not our case. Thus, alkyl hydroperoxides are not formed in the course of the oxidation (for the method, see References [46-56]). The yield of tertiary alcohols attained 53\% based on MCPBA (Table 3, run 22). In many cases shown in Table 3 the reaction proceeds stereoselectively, the highest parameter trans $/$ cis $=0.05-0.07$ was attained for catalysts $\mathbf{1}, \mathbf{2}$ and 3. The lowest ratios trans/cis have been achieved when nitric acid in low concentration has been added to the reaction solution.

Table 3. Oxygenation of isomeric dimethylcyclohexanes with MCPBA catalyzed by cobalt complexes ${ }^{1}$.

\begin{tabular}{|c|c|c|c|c|c|c|c|c|}
\hline Run & Cat & Substrate & $\begin{array}{l}{\left[\mathrm{HNO}_{3}\right]} \\
(\mathrm{mM})\end{array}$ & $\begin{array}{l}\text { Time } \\
\text { (min) }\end{array}$ & $\begin{array}{c}t \text {-Dimethyl-Alcohol } \\
(\mathrm{mM})\end{array}$ & $\begin{array}{c}c \text {-Dimethyl-Alcohol } \\
(\mathrm{mM})\end{array}$ & $\begin{array}{l}\text { Yield } \\
(\%)\end{array}$ & $\begin{array}{c}\text { Ratio } \\
\text { trans/cis }\end{array}$ \\
\hline 1 & None & cis-1,2-DMCH & 0 & 30 & 0.13 & 0.17 & 0.2 & 0.76 \\
\hline 2 & None & cis-1,2-DMCH & 0 & 120 & 2.9 & 4.1 & 5 & 0.74 \\
\hline 4 & 1 & cis-1,2-DMCH & 0 & 30 & 3 & 23 & 19 & 0.13 \\
\hline 5 & & cis-1,2-DMCH & 0 & 120 & 4 & 29 & 24 & 0.14 \\
\hline 6 & & cis-1,2-DMCH ${ }^{2}$ & 50 & 120 & 2.4 & 52 & 39 & 0.05 \\
\hline 9 & & cis-1,2-DMCH & $50^{4}$ & 30 & 8 & 12 & 14 & 0.70 \\
\hline 10 & & trans-1,2-DMCH & 0 & 30 & 19 & 8 & 19 & 2.4 \\
\hline 11 & & trans-1,2-DMCH & 0 & 120 & 19 & 8 & 19 & 2.4 \\
\hline 12 & & trans-1,2-DMCH & 50 & 30 & 26 & 1 & 19 & 19 \\
\hline
\end{tabular}


Table 3. Cont.

\begin{tabular}{|c|c|c|c|c|c|c|c|c|}
\hline Run & Cat & Substrate & $\begin{array}{l}{\left[\mathrm{HNO}_{3}\right]} \\
(\mathrm{mM})\end{array}$ & $\begin{array}{l}\text { Time } \\
\text { (min) }\end{array}$ & $\begin{array}{l}t \text {-Dimethyl-Alcohol } \\
(\mathrm{mM})\end{array}$ & $\begin{array}{c}c \text {-Dimethyl-Alcohol } \\
(\mathrm{mM})\end{array}$ & $\begin{array}{c}\text { Yield } \\
(\%)\end{array}$ & $\begin{array}{c}\text { Ratio } \\
\text { trans/cis }\end{array}$ \\
\hline 13 & & trans-1,2-DMCH & 50 & 120 & 36 & 2 & 27 & 21 \\
\hline 14 & & trans-1,2-DMCH & 50 & 30 & 13 & 8 & 15 & 1.6 \\
\hline 15 & & trans-1,2-DMCH & $50^{4}$ & 120 & 14 & 9 & 16 & 1.5 \\
\hline 16 & & cis-1,4-DMCH & 50 & 30 & 3 & 48 & 37 & 0.07 \\
\hline 17 & & cis-1,4-DMCH & 50 & 120 & 14 & 9 & 43 & 0.11 \\
\hline 18 & & trans-1,4-DMCH & 50 & 30 & 30 & 3 & 23 & 12 \\
\hline 20 & 2 & cis-1,2-DMCH & 0 & 120 & 10 & 32 & 30 & 0.28 \\
\hline 21 & & cis-1,2-DMCH & 50 & 30 & 3.5 & 44 & 34 & 0.08 \\
\hline 22 & & cis-1,2-DMCH & 50 & 120 & 4 & 69 & 53 & 0.06 \\
\hline 23 & 3 & cis-1,2-DMCH & 50 & 30 & 3.5 & 50 & 35 & 0.07 \\
\hline 24 & & cis-1,2-DMCH & 50 & 120 & 4 & 61 & 46 & 0.07 \\
\hline 25 & 4 & cis-1,2-DMCH & 50 & 30 & 3 & 37 & 26 & 0.08 \\
\hline 30 & & cis-1,2-DMCH & 50 & 180 & 4 & 10 & 10 & 0.4 \\
\hline 31 & 6 & cis-1,2-DMCH & 50 & 30 & 3 & 39 & 30 & 0.08 \\
\hline 32 & & cis-1,2-DMCH & 50 & 120 & 3 & 40 & 30 & 0.07 \\
\hline 33 & 7 & cis-1,2-DMCH & 50 & 300 & 3 & 6 & 6 & 0.5 \\
\hline 34 & 8 & cis-1,2-DMCH & 50 & 30 & 17 & 54 & 50 & 0.3 \\
\hline 35 & & cis-1,2-DMCH & 50 & 120 & 17 & 57 & 53 & 0.3 \\
\hline 36 & 9 & cis-1,2-DMCH & 50 & 30 & 4.5 & 6 & 7 & 0.82 \\
\hline 37 & & cis-1,2-DMCH & 50 & 120 & 4.5 & 6 & 7 & 0.82 \\
\hline 38 & 10 & cis-1,2-DMCH & 50 & 30 & 3 & 4 & 5 & 0.84 \\
\hline 39 & & cis-1,2-DMCH & 50 & 120 & 3 & 4 & 5 & 0.84 \\
\hline
\end{tabular}

${ }^{1}$ Reactions were performed in $\mathrm{MeCN}$ (total volume $2.5 \mathrm{~mL}$ ). Concentrations: [Substrate $]_{0}=140 \mathrm{mM}$, $[\mathrm{MCPBA}]_{0}=260 \mathrm{mM}$, catalyst $[\text { Cat }]_{0}=0.5 \mathrm{mM}, 40{ }^{\circ} \mathrm{C}$. Samples were analyzed by GC after reduction with $\mathrm{PPh}_{3}$. $t$-Dimethyl and $c$-dimethyl alcohol are tertiary alcohols with trans- and cis-mutual orientation of methyl groups, respectively. The ratio trans/cis is the ratio of these two isomers. Parameters for entries 22 and 35 were TON $=150$ and TOF $=75 \mathrm{~h}^{-1} ;^{2}$ The chromatogram obtained for the reaction solution before reduction with $\mathrm{PPh}_{3}$ ( $t$-dimethyl alcohol, $2.5 \mathrm{mM}$; $t$-dimethyl alcohol, $52 \mathrm{mM}$ ) did not practically distinguish from the data obtained for the reduced sample; ${ }^{3}$ Trifluoroacetic acid $(50 \mathrm{mM})$ was used instead of nitric acid; ${ }^{4} \mathrm{Salt}_{\mathrm{LiNO}}$ $(50 \mathrm{mM})$ was used instead of nitric acid.

The data collected in Table 3 allow us to compare activities and stereoselectivity parameters of different cobalt complexes. Table 3 indicates sufficiently different catalytic activities and stereoselectivity parameters in the oxidations catalyzed by different cobalt complexes. Addition of nitric acid greatly enhances the efficiency in all cases. In the hydroxylation of cis-1,2-dimethylcyclohexane complexes 1 and $\mathbf{8}$ exhibit the highest activity (yields are 39\% and 53\% after $2 \mathrm{~h}$ ). However, the oxidation catalyzed by complex $\mathbf{1}$ is much more selective (trans/cis $=0.05$ ) than that in the presence of compound $\mathbf{8}$ (trans/cis $=0.3$ ). Complexes $\mathbf{9}$ and $\mathbf{1 0}$ containing bulky 1,1'-dipyridil ligands are very poor and non-stereoselective catalysts which is apparently due to sterical hindrance around the reaction center. Previously, Nam et al. [16] in the oxidation catalyzed by $\mathrm{Co}\left(\mathrm{ClO}_{4}\right)_{2}$ used large excess of cis-1,2-dimethylcyclohexane $(1 \mathrm{mmol})$ over MCPBA $(0.02 \mathrm{mmol})$ and obtained the oxygenates in $80 \%$ yield based in the oxidant. We introduced into the reaction low amount of the expensive substrate $(140 \mathrm{mM})$ and larger concentration of MCPBA $(260 \mathrm{mM})$. In our case, hydroxylated products were obtained in high yield: $53 \%$ based on the substrate.

\subsection{Studies of Obtained Complexes by Electrospray Ionization/Mass Spectrometry (ESI-MS) Method}

In order to determine possible organo-cobalt spices responsible for the catalytic oxidation of alkanes by MCPBA, we investigated the reaction of the obtained cobalt complexes with $\mathrm{HNO}_{3}$ by the ESI-MS method, which is a common tool to gain mechanistic insights into homogeneous metal-catalyzed reactions [92]. The primary reaction of containing bidentate nitrogen ligands iodide complexes 7, 9, and 10 with $\mathrm{HNO}_{3}$ in acetonitrile leads to the replacement of iodide with either a nitrate anion or an acetonitrile molecule. Thus, the ESI-MS spectrum of the reaction mixture with complex 7 (Figure 6) reveals two main peaks corresponding to ionic fragments $\left[\mathrm{Cp} * \mathrm{Co}(\mathrm{phen})\left(\mathrm{CH}_{3} \mathrm{CN}\right)\right]^{2+}$ 
$(m / z=207.8)$ and $\left[\mathrm{Cp} * \mathrm{Co}(\mathrm{phen})\left(\mathrm{NO}_{3}\right)\right]^{+}(m / z=436.0)$. It can be concluded on the basis of Table 3 (runs 33, 36-39) that complexes 7, 9, and 10 containing phenanthroline or dipyridine ligands are the poorest catalysts in the alkane oxygenation.

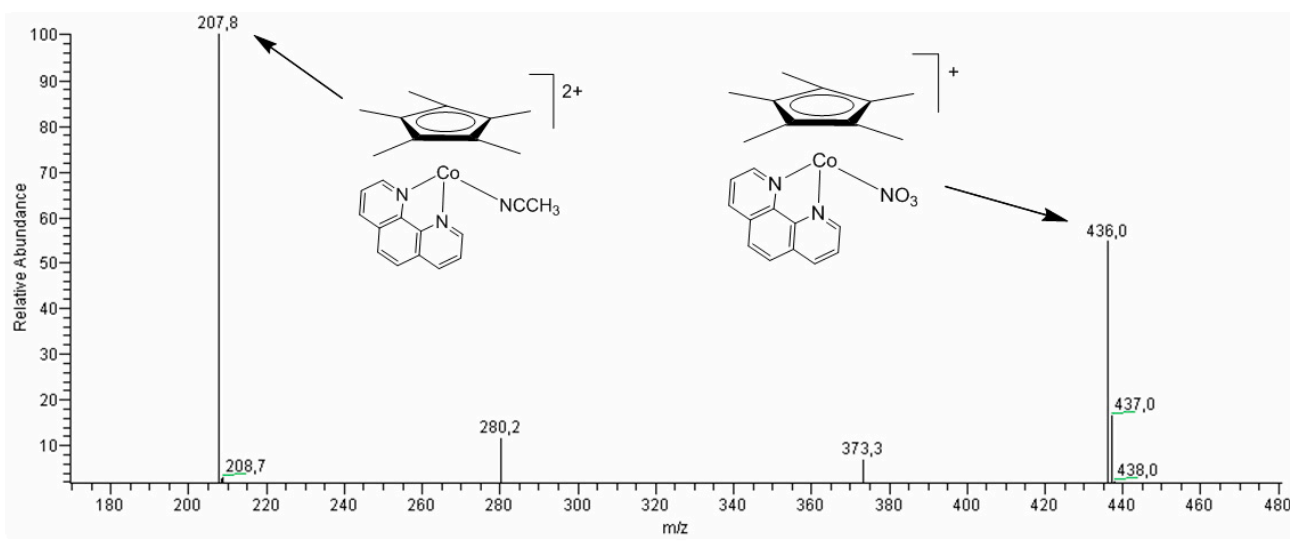

Figure 6. The ESI-MS spectrum (positive-ion mode) of the reaction mixture of complex 7 and $\mathrm{HNO}_{3}$ in acetonitrile solution at $55^{\circ} \mathrm{C}$ after $1 \mathrm{~h}$. Concentrations: $[7]_{0}=6.5 \times 10^{-4} \mathrm{M},\left[\mathrm{HNO}_{3}\right]_{0}=0.04 \mathrm{M}$. Total volume of the reaction mixture was $3 \mathrm{~mL}$.

In contrast, interaction of $\mathrm{HNO}_{3}$ under the same reaction conditions with complexes 3, 6, and 8 results in complete decomposition of the complexes to form solvated $\mathrm{Co}^{2+}$ salts detected by the appearance of two characteristic peaks in the ESI-MS spectra with $m / z=152.3$ and 243.5 (Figure 7) attributed to species $\left[\mathrm{Co}(\mathrm{MeCN})_{6}\right]^{2+}$ and $\left[\mathrm{Co}(\mathrm{MeCN})_{3}\left(\mathrm{NO}_{3}\right)\right]^{+}$, respectively. The catalysts 3-6, and 8 exhibited in the oxidation moderate yield and stereoselectivity (see Table 3). Noteworthy, although complexes 3, 6, and 8 heated with $\mathrm{HNO}_{3}$ exhibit the same patterns in the ESI-MS spectra they have different behavior in the catalytic oxidation of cis-1,2-DMCH. The oxidation stereoselectivity in the case of complex 8 is lower than that for complexes 3 and $\mathbf{6}$. It can be due to lower bulkiness of active species formed from 8 in comparison with the case of pre-catalysts 3 and 6 .

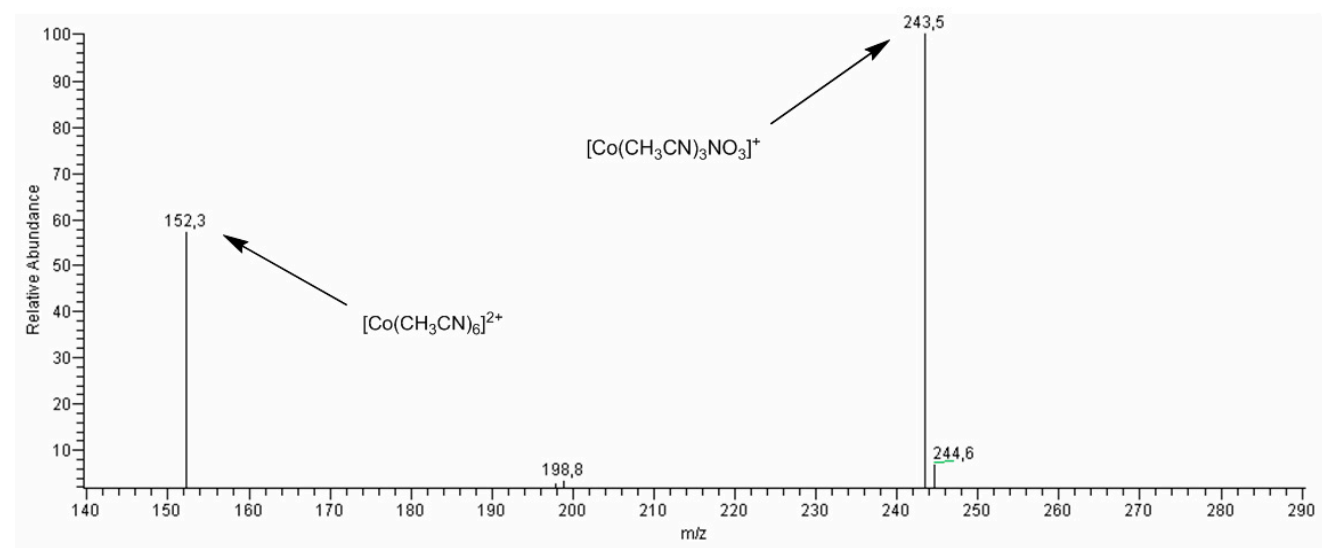

Figure 7. The ESI-MS spectrum (positive-ion mode) of the reaction mixture of complex 6 and $\mathrm{HNO}_{3}$ in acetonitrile solution at $55^{\circ} \mathrm{C}$ after $1 \mathrm{~h}$. Concentrations: $[6]_{0}=6.5 \times 10^{-4} \mathrm{M},\left[\mathrm{HNO}_{3}\right]_{0}=0.04 \mathrm{M}$. Total volume of the reaction mixture was $3 \mathrm{~mL}$.

It is interesting that efficient in stereoselective oxidation complex 1 (Table 3, runs 4-19) was significantly more stable toward $\mathrm{HNO}_{3}$. After heating in acetonitrile during $1 \mathrm{~h}$ at $55^{\circ} \mathrm{C}$ the ESI-MS spectrum reveals the sole signal $(m / z=245)$ corresponding to the starting cation $\left[\mathrm{Cb}{ }^{*} \mathrm{Co}\left(\mathrm{C}_{6} \mathrm{H}_{6}\right)\right]^{+}$. However, addition of MCPBA and prolonged heating for $1 \mathrm{~h}$ leads to appearance of extra signals in the 
spectrum (Figure 8), which clearly indicates the interaction of 1 with MCPBA leading to the activation of pre-catalyst $\left[\mathrm{Cb}^{*} \mathrm{Co}\left(\mathrm{C}_{6} \mathrm{H}_{6}\right)\right]^{+}$.

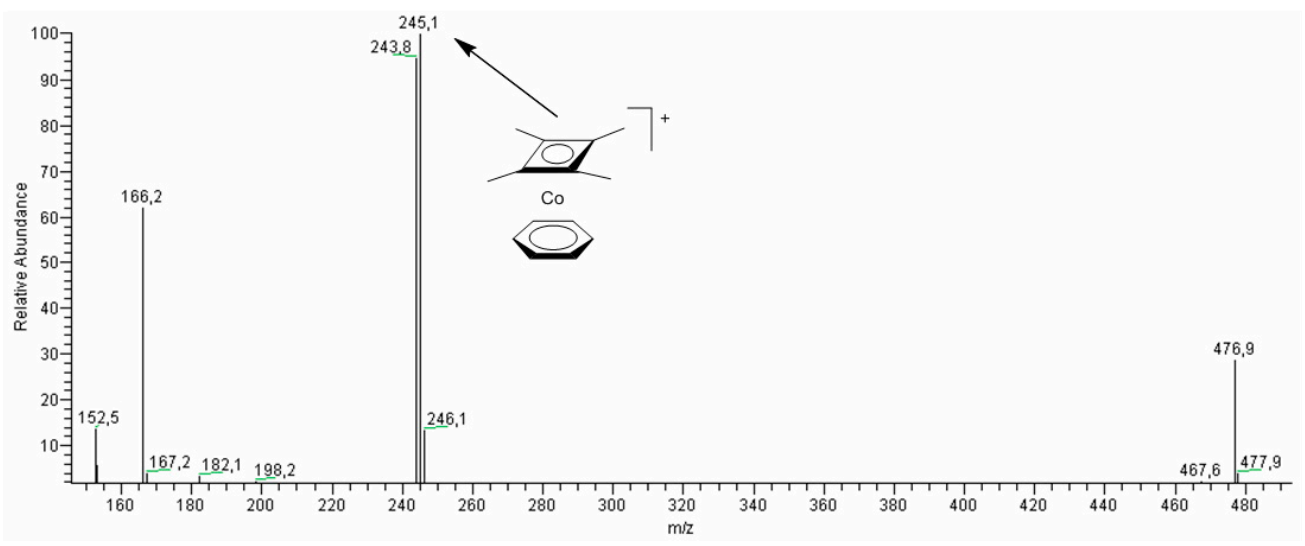

Figure 8. The ESI-MS spectrum (positive-ion mode) of the reaction mixture of complex 1 with $\mathrm{HNO}_{3}$ and MCPBA in acetonitrile solution at $55^{\circ} \mathrm{C}$ after $1 \mathrm{~h}$. Concentrations: $[1]_{0}=6.5 \times 10^{-4} \mathrm{M}$, $\left[\mathrm{HNO}_{3}\right]_{0}=0.04 \mathrm{M},[\mathrm{MCPBA}]_{0}=0.015 \mathrm{M}$. Total volume of the reaction mixture was $3 \mathrm{~mL}$.

\subsection{On the Mechanism of Catalyzed $\mathrm{C}-\mathrm{H}$ Bond Oxidation with MCPBA}

We demonstrated in Section 2.5 that the catalyzed alkane oxidation with $\mathrm{H}_{2} \mathrm{O}_{2}$ affords predominantly alkyl hydroperoxides because the treatment of the reaction solution with $\mathrm{PPh}_{3}$ leads to the decrease of the ketone peak and increase of the alcohol peak in GC [55] (compare entries 1 and 2 in Table 1). The cyclohexane oxidation with MCPBA catalyzed by the manganese salt affords some amount of cyclohexyl hydroperoxide (Figure 5). On the contrary, catalysis by cobalt complexes of the oxidation of dimethycyclohexane with MCPBA led to the identical results for the product content measured before and after reduction with $\mathrm{PPh}_{3}$ (see Table 3, run 6). Thus, we may conclude that alkyl hydroperoxides are not formed in the oxidation with MCPBA and that free radicals are not involved into the process. The reaction most probably proceeds via the concerted mechanism with peroxide oxygen insertion into the alkane $\mathrm{C}-\mathrm{H}$ bond $[37,42,61]$.

\section{Materials and Methods}

\subsection{General}

The syntheses were carried out under an inert atmosphere in dry solvents. The isolation of products was conducted in air. Hydrogen peroxide, TBHP, and MCPBA were used as oxidants. Acetonitrile was employed as solvent in all oxidations. ${ }^{1} \mathrm{H}-\mathrm{NMR}$ spectra $(\delta$ in $\mathrm{ppm})$ were recorded on a Bruker Avance-400 spectrometer (Moscow, Russia) (400.13 MHz) relative to residual protons of the solvents.

\subsection{Syntheses of Complexes}

The isolation of products was conducted in air. Catalysts $\left[\left(\mathrm{C}_{4} \mathrm{Me}_{4}\right) \mathrm{Co}\left(\mathrm{C}_{6} \mathrm{H}_{6}\right)\right] \mathrm{PF}_{6}$ (1) [93], $\mathrm{Cp}^{*} \mathrm{Co}(\mathrm{CO}) \mathrm{I}_{2}$ (2) [94], $\mathrm{CpCo}(\mathrm{CO}) \mathrm{I}_{2}$ (3) [95], $\left(\mathrm{C}_{4} \mathrm{Me}_{4}\right) \mathrm{Co}(\mathrm{CO})_{2} \mathrm{I}(4)$ [93], $\left[\left(\mathrm{C}_{4} \mathrm{H}_{4} \mathrm{BCy}\right) \mathrm{Co}(\mathrm{CO})_{2}\right]_{2}$ (6) [96], and $\left[\mathrm{CpCoI}_{2}\right]_{n}(8)[97]$ have been described previously in the literature. Complex $[\mathrm{CpCo}(\mathrm{bipy}) \mathrm{I}] \mathrm{PF}_{6}(\mathbf{9})$ was prepared by King's method [95] in high yield, with the use of the improved counterion-exchange procedure described below.

Compound $\left[\left(\mathrm{C}_{4} \mathrm{Me}_{4}\right) \mathrm{Co}(\right.$ bipy $\left.)(\mathrm{MeCN})\right] P F_{6}$ (5). A solution of the complex $\left[\left(\mathrm{C}_{4} \mathrm{Me}_{4}\right) \mathrm{Co}\left(\mathrm{C}_{6} \mathrm{H}_{6}\right)\right] \mathrm{PF}_{6}(\mathbf{1})$ $(100 \mathrm{mg}, 0.26 \mathrm{mmol})$ in acetonitrile $(3 \mathrm{~mL})$ was irradiated using mercury luminescent lamp $(400 \mathrm{~W})$ for $2 \mathrm{~h}$ with the use of a running water cooler for $2 \mathrm{~h} .2,2^{\prime}$-Bipyridyl $(44 \mathrm{mg}, 0.28 \mathrm{mmol}$ ) was added to the obtained solution. The reaction mixture was stirred overnight. The solvent was removed in vacuo. 
The residue was extracted with $\mathrm{CH}_{2} \mathrm{Cl}_{2}$ and ether was added. The precipitate was filtered off, washed with ether, and dried in vacuo. Yield of compound $\left[\left(\mathrm{C}_{4} \mathrm{Me}_{4}\right) \mathrm{Co}(\right.$ bipy $\left.)(\mathrm{MeCN})\right] \mathrm{PF}_{6}(5)$ obtained as an orange solid was $63 \mathrm{mg}(48 \%)$. Anal. Calc. for $\mathrm{C}_{20} \mathrm{H}_{23} \mathrm{~N}_{3} \mathrm{CoF}_{6} \mathrm{P}: \mathrm{C}, 47.16 ; \mathrm{H}, 4.56 ; \mathrm{N}, 8.25 \%$. Found: $\mathrm{C}, 46.31 ; \mathrm{H}, 4.59 ; \mathrm{N}, 8.52 \% .{ }^{1} \mathrm{H}-\mathrm{NMR}$ (acetone- $\left.d_{6}\right): \delta=8.99(\mathrm{~d}, J=5.2 \mathrm{~Hz}, 2 \mathrm{H}$, bipy), $8.66(\mathrm{~d}, J=8.0 \mathrm{~Hz}$, $2 \mathrm{H}$, bipy), 8.29 (m, $2 \mathrm{H}$, bipy), 7.83 (m, $2 \mathrm{H}$, bipy), 1.31 (s, $12 \mathrm{H}, \mathrm{C}_{4} \mathrm{Me}_{4}$ ).

Compound $\left[C p^{*} \mathrm{Co}(\right.$ phen $\left.) I\right] P F_{6}(7)$. Benzene $(5 \mathrm{~mL})$ was added to a mixture of complex $\mathrm{Cp} \mathrm{P}^{*} \mathrm{Co}(\mathrm{CO}) \mathrm{I}_{2}$ $(3,120 \mathrm{mg}, 0.24 \mathrm{mmol})$ and phen $(56 \mathrm{mg}, 0.36 \mathrm{mmol})$. The reaction mixture was stirred overnight. The solvent was removed in vacuo. The complex [C $\mathrm{p}^{*} \mathrm{Co}$ (phen)I]I was extracted from the residue with water. Then an excess of an aqueous $\mathrm{KPF}_{6}$ solution was added. The black precipitate that formed was filtered off, washed with water, and dried in vacuo. Reprecipitation from acetonitrile with ether gave complex $\left[\mathrm{Cp}^{*} \mathrm{Co}\right.$ (phen)I]PF $6(7,70 \mathrm{mg}, 45 \%)$ as a black solid. Anal. Calc. for $\mathrm{C}_{22} \mathrm{H}_{23} \mathrm{~N}_{2} \mathrm{CoIF}_{6} \mathrm{P}: \mathrm{C}, 40.89$; H, 3.59; N, 4.33\%. Found: C, 41.03; H, 3.44; N, 4.51\%. ${ }^{1} \mathrm{H}-\mathrm{NMR}$ (acetonitrile- $\left.d_{3}\right): \delta=9.71(\mathrm{~d}, J=5.2 \mathrm{~Hz}$, $2 \mathrm{H}$, phen), $8.72\left(\mathrm{~d}, J=8.0 \mathrm{~Hz}, 2 \mathrm{H}\right.$, phen), 8.14 (m, $4 \mathrm{H}$, phen), 1.60 (s, $\left.15 \mathrm{H}, \mathrm{Cp}^{*}\right)$.

Compound [CpCo(bipy)I]PF 6 (9). Complex [CpCo(bipy)I] $\mathrm{PF}_{6}$ was prepared by King's method [95] in high yield, with the use of the improved counterion-exchange procedure given below. Benzene $(5 \mathrm{~mL})$ was added to a mixture of complex $\mathrm{CpCo}(\mathrm{CO}) \mathrm{I}_{2}$ [95] $(3,120 \mathrm{mg}, 0.28 \mathrm{mmol})$ and bipy $(73 \mathrm{mg}$, $0.55 \mathrm{mmol}$ ). The reaction mixture was stirred overnight. The precipitate of [CpCo(bipy)I]I was filtered off, washed with benzene and ether, and dried in vacuo. The precipitate was extracted with water. Then an excess of an aqueous $\mathrm{KPF}_{6}$ solution was added. The dark violet precipitate that formed was filtered off, washed with water, and dried in vacuo. Reprecipitation from acetone with ether gave complex [CpCo(bipy)I] $\mathrm{PF}_{6}(\mathbf{9}, 126 \mathrm{mg}, 86 \%)$ as a dark violet solid. ${ }^{1} \mathrm{H}-\mathrm{NMR}$ (acetone- $\left.d_{6}\right): \delta=10.07$ (d, $J=5.2 \mathrm{~Hz}, 2 \mathrm{H}$, bipy), 8.54 (d, J = 8.0 Hz, $2 \mathrm{H}$, bipy), 8.33 (m, $2 \mathrm{H}$, bipy), 7.87 (m, 2 H, bipy), 6.18 (s, $5 \mathrm{H}, \mathrm{Cp})$.

Compound $\left[C p^{*} \mathrm{Co}(\right.$ bipy $\left.) I\right] P F_{6}(\mathbf{1 0})$. Benzene $(5 \mathrm{~mL})$ was added to a mixture of complex $\mathrm{Cp} \mathrm{P}^{*} \mathrm{Co}(\mathrm{CO}) \mathrm{I}_{2}$ $(2,120 \mathrm{mg}, 0.24 \mathrm{mmol})$ and bipy $(47 \mathrm{mg}, 0.36 \mathrm{mmol})$. The reaction mixture was stirred overnight. The solvent was removed in vacuo. The complex [Cp*Co(bipy)I]I was extracted from the residue with water and methanol. Then an excess of an aqueous $\mathrm{KPF}_{6}$ solution was added. The black precipitate that formed was filtered off, washed with water, and dried in vacuo. Reprecipitation from acetone with ether gave complex [C ${ }^{*} \mathrm{Co}\left(\right.$ bipy)I] $\mathrm{PF}_{6}(\mathbf{1 0}, 47 \mathrm{mg}, 32 \%)$ as a black solid. Anal. Calc. for $\mathrm{C}_{20} \mathrm{H}_{23} \mathrm{~N}_{2} \mathrm{CoIF}_{6} \mathrm{P}: \mathrm{C}, 38.62 ; \mathrm{H}, 3.70 ; \mathrm{N}, 4.50 \%$. Found: C, 38.69; H, 3.68; N, 4.46\%. ${ }^{1} \mathrm{H}-\mathrm{NMR}$ (acetone- $\left.d_{6}\right)$ : $\delta=9.61(\mathrm{~d}, J=5.6 \mathrm{~Hz}, 2 \mathrm{H}$, bipy), 8.58 (d, J = 8.0 Hz, $2 \mathrm{H}$, bipy), 8.35 (m, $2 \mathrm{H}$, bipy), 7.95 (m, 2 H, bipy), $1.68\left(\mathrm{~s}, 15 \mathrm{H}, \mathrm{Cp}^{*}\right)$.

\subsection{X-ray Diffraction Study}

Crystals were grown by slow diffusion in a two-layer system of ether/petroleum ether mixture with solution of complex in acetonitrile (for $\left[\mathrm{Cp}^{*} \mathrm{Co}(\mathrm{phen}) \mathrm{I}\right] \mathrm{PF}_{6}(7)$ ) or acetone (for $\left[\mathrm{CpCo}\left(\mathrm{bipy}_{\mathrm{p}} \mathrm{I}\right] \mathrm{PF}_{6}\right.$ (9) and $\left[\mathrm{Cp}^{*} \mathrm{Co}\right.$ (bipy)I] $\left.\mathrm{PF}_{6}(\mathbf{1 0})\right)$. X-ray diffraction data for 10 were collected with Bruker Apex2 DUO diffractometer (Moscow, Russia) at $100 \mathrm{~K}$ and those for 7 and 9 with Bruker Apex 2 diffractometer at 120 and $100 \mathrm{~K}$, respectively, using graphite monochromated Mo-K $\alpha$ radiation $(\lambda=0.71073 \AA$, $\omega$-scans). The structures were solved by the direct method and refined by the full-matrix least-squares against $\mathrm{F}^{2}$ in anisotropic approximation for non-hydrogen atoms. The positions of hydrogen atoms were calculated, and they were refined in isotropic approximation in riding model. Crystal data and structure refinement parameters for 7, 9, and $\mathbf{1 0}$ are collected in Table 4. All calculations were performed using the SHELXTL PLUS 5.0 [98]. CCDC 1504665, 1504667 and 1504666 contain the supplementary crystallographic data for 7, 9, and 10, respectively. These data can be obtained free of charge via www.ccdc.cam.ac.uk/data_request/cif.

The molecular structures, bond lengths and angles as well as crystallographic data and structure refinement parameters of the three catalysts 7, 9, and 10 obtained in this work are given in Figures 1-3 above and Table 4 below. 
Table 4. Crystallographic data and structure refinement parameters for 7, 9, and $\mathbf{1 0 .}$

\begin{tabular}{|c|c|c|c|}
\hline Compound & 7 & 9 & 10 \\
\hline Empirical formula & $\mathrm{C}_{22} \mathrm{H}_{23} \mathrm{CoF}_{6} \mathrm{IN}_{2} \mathrm{P}$ & $\mathrm{C}_{15} \mathrm{H}_{13} \mathrm{CoF}_{6} \mathrm{IN}_{2} \mathrm{P}$ & $\mathrm{C}_{20} \mathrm{H}_{23} \mathrm{CoF}_{6} \mathrm{IN}_{2} \mathrm{P}$ \\
\hline Formula weight & 646.22 & 552.07 & 622.20 \\
\hline Crystal system & Triclinic & Orthorhombic & Monoclinic \\
\hline Space group & $P-1$ & $\mathrm{Pna}_{1}$ & $P 2_{1} / n$ \\
\hline$a(\AA)$ & $8.2684(9)$ & $16.7546(14)$ & $9.0966(18)$ \\
\hline$b(\AA)$ & $11.4505(13)$ & $8.4636(7)$ & $26.448(5)$ \\
\hline$c(\AA)$ & $12.4520(14)$ & $24.681(2)$ & $9.2018(17)$ \\
\hline$\alpha\left({ }^{\circ}\right)$ & $87.800(2)$ & - & - \\
\hline$\beta\left(^{\circ}\right)$ & $84.628(2)$ & - & $90.574(4)$ \\
\hline$\gamma\left({ }^{\circ}\right)$ & $77.714(2)$ & - & - \\
\hline$V\left(\AA^{3}\right)$ & $1146.7(2)$ & $3499.9(5)$ & $2213.7(7)$ \\
\hline$D_{\text {calc }}\left(\mathrm{g} \cdot \mathrm{cm}^{-3}\right)$ & 1.872 & 2.095 & 1.867 \\
\hline Linear absorption, $\mu\left(\mathrm{cm}^{-3}\right)$ & 22.27 & 28.98 & 23.02 \\
\hline $\mathrm{F}(000)$ & 636 & 2128 & 1224 \\
\hline $2 \theta_{\max }^{\circ}$ & 56 & 52 & 54 \\
\hline Reflections measured & 20,367 & 31,839 & 28,418 \\
\hline Independent reflections & $5529\left(R_{\text {int }}=0.0416\right)$ & $6888\left(R_{\mathrm{int}}=0.0642\right)$ & $4819\left(R_{\mathrm{int}}=0.1797\right)$ \\
\hline Observed reflections $(I>2 \sigma(I))$ & 4730 & 6398 & 4320 \\
\hline Parameters & 303 & 484 & 307 \\
\hline$R_{1}$ & 0.0301 & 0.0620 & 0.0739 \\
\hline$w R_{2}$ & 0.0800 & 0.1721 & 0.2145 \\
\hline Goodness-of-fit & 1.017 & 1.271 & 1.477 \\
\hline Largest diff. peak and hole $\left(\mathrm{e} \AA^{-3}\right)$ & 1.44 and -0.72 & 2.49 and -1.51 & 2.34 and -1.92 \\
\hline
\end{tabular}

\subsection{Catalytic Oxidation of Alkanes and 1-Phenylethanol}

Typically, catalyst and the co-catalyst (nitric or trifluoroacetic acid) were introduced into the reaction mixture in the form of stock solutions in acetonitrile. The reactions of alcohols and hydrocarbons were carried out in air in thermostated Pyrex cylindrical vessels with vigorous stirring and using $\mathrm{MeCN}$ as solvent. The substrate (alcohol or hydrocarbon) was then added and the reaction started when the oxidant was introduced in one portion. (CAUTION: The combination of air or molecular oxygen and peroxides with organic compounds at elevated temperatures may be explosive!). The reactions with 1-phenylethanol were analyzed by ${ }^{1} \mathrm{H}-\mathrm{NMR}$ method (solutions in acetone- $d_{6}$; "Bruker AMX-400" instrument, $400 \mathrm{MHz}$ ). Areas of methyl group signals were measured to quantify oxygenates formed in oxidations of 1-phenylethanol. As we made previously, the samples obtained in the alkane oxidation were typically analyzed twice (before and after their treatment with $\mathrm{PPh}_{3}$ ) by GC. This method (comparison of chromatograms of the same sample obtained before and after addition of $\mathrm{PPh}_{3}$ ) was proposed by Shul'pin earlier [46-56] and allows us to estimate real concentration of alkyl hydroperoxide, ketone (aldehyde and alcohol) present in the reaction solution. Samples of the reaction mixture were analyzed by GC (the chromatograph-3700; fused silica capillary column FFAP/OV-101 20/80 w/w, $30 \mathrm{~m} \times 0.2 \mu \mathrm{m} \times 0.3 \mu \mathrm{m}$; helium as a carrier gas). Attribution of peaks was made by comparison with chromatograms of authentic samples and by GC-MS (INEOS, Moscow, Russia).

Acknowledgments: The authors gratefully acknowledge support of the Russian Foundation for Basic Research (projects 16-03-00254, and 16-29-10672).

Author Contributions: G.B.S. and D.A.L. conceived and designed experiments on synthesis and catalytic application of cobalt compounds; D.A.L., V.O.I. and S.N.O. made synthesis of the complexes; L.S.S., N.S.I., M.M.V. and P.M.T. performed experiments on oxidations and analysis of products by GC and ESI-MS; Y.V.N. carried out X-ray experiments and their analysis; and G.B.S. and D.A.L. wrote the paper.

Conflicts of Interest: The authors declare no conflict of interest. 


\section{References}

1. Shilov, A.E.; Shul'pin, G.B. Activation and Catalytic Reactions of Saturated Hydrocarbons in the Presence of Metal Complexes; Kluwer Academic Publishers: New York, NY, USA; Boston, MA, USA; Dordrecht, The Netherlands; London, UK; Moscow, Russia, 2002.

2. Denisov, E.T.; Afanas'ev, I.B. Oxidation and Antioxidants in Organic Chemistry and Biochemistry; Taylor \& Francis: Boca Raton, FL, USA; London, UK; New York, NY, USA; Singapore, Singapore, 2005.

3. Clerici, M.G.; Kholdeeva, O.A. Liquid Phase Oxidation via Heterogeneous Catalysis; Wiley: Hoboken, NJ, USA, 2013.

4. Munz, D.; Strassner, T. Alkane C-H functionalization and oxidation with molecular oxygen. Inorg. Chem. 2015, 54, 5043-5052. [CrossRef] [PubMed]

5. Shilov, A.E.; Shul'pin, G.B. Activation of C-H Bonds by Metal Complexes. Chem. Rev. 1997, 97, $2879-2932$. [CrossRef]

6. Chepaikin, E.G. Homogeneous catalysis in the oxidative functionalization of alkanes in protic media. Russ. Chem. Rev. 2011, 80, 363-396. [CrossRef]

7. Costas, M. Selective C-H oxidation catalyzed by metalloporphyrins. Coord. Chem. Rev. 2011, 255, $2912-2932$. [CrossRef]

8. Pérez, P.J. Alkane C-H Activation by Single-Site Metal Catalysis; Springer: Heidelberg, Germany, 2012.

9. Sivaramakrishna, A.; Suman, P.; Goud, E.V.; Janardan, S.; Sravani, C.; Sandep, T.; Vijayakrishna, K.; Clayton, H.S. Review: Active homogeneous reagents and catalysts in $n$-alkane activation reactions. J. Coord. Chem. 2013, 66, 2091-2109. [CrossRef]

10. Sorokin, A.B. Phthalocyanine Metal Complexes in Catalysis. Chem. Rev. 2013, 113, 8152-8191. [CrossRef] [PubMed]

11. Caballero, A.; Perez, P.J. Methane as raw material in synthetic chemistry: The final frontier. Chem. Soc. Rev. 2013, 42, 8809-8820. [CrossRef] [PubMed]

12. Shul'pin, G.B. Selectivity in C-H functionalizations. In Comprehensive Inorganic Chemistry II, 2nd ed.; Reedijk, J., Poeppelmeier, K., Casella, L., Eds.; Elsevier: Amsterdam, The Netherlands, 2013; Volume 6, Chapter 6.04, pp. 79-104.

13. Chepaikin, E.G. Oxidative functionalization of alkanes under dioxygen in the presence of homogeneous noble metal catalysts. J. Mol. Catal. A Chem. 2014, 385, 160-174. [CrossRef]

14. Landaeta, V.R.; Rodríguez-Lugo, R.E. Catalytic oxygenation of organic substrates: Toward greener ways for incorporating oxygen. Inorg. Chim. Acta 2015, 431, 21-47. [CrossRef]

15. Nam, W.; Kim, I.; Kim, Y.; Kim, C. Biomimetic alkane hydroxylation by cobalt(III) porphyrin complex and m-chloroperbenzoic acid. Chem. Commun. 2001, 1262-1263. [CrossRef]

16. Nam, W.; Ryu, J.Y.; Kim, I.; Kim, C. Stereoselective alkane hydroxylations by metal salts and m-chloroperbenzoic acid. Tetrahedron Lett. 2002, 43, 5487-5490. [CrossRef]

17. Strassner, T.; Ahrens, S.; Muehlhofer, M.; Munz, D.; Zeller, A. Cobalt-catalyzed oxidation of methane to methyl trifluoroacetate by dioxygen. Eur. J. Inorg. Chem. 2013, 3659-3663. [CrossRef]

18. Tordin, E.; List, M.; Monkowius, U.; Schindler, S.; Knör, G. Synthesis and characterisation of cobalt, nickel and copper complexes with tripodal $4 \mathrm{~N}$ ligands as novel catalysts for the homogeneous partial oxidation of alkanes. Inorg. Chim. Acta 2013, 402, 90-96. [CrossRef] [PubMed]

19. Silva, T.F.S.; Martins, L.M.D.R.S.; Guedes da Silva, M.F.C.; Kuznetsov, M.L.; Fernandes, A.R.; Silva, A.; Pan, C.-J.; Lee, J.-F.; Hwang, B.-J.; Pombeiro, A.J.L. X-ray Absorption Spectroscopy Studies and Biological Applications. Chem. Asian J. 2014, 9, 1132-1143. [CrossRef] [PubMed]

20. Xing, N.; Xu, L.T.; Bai, F.Y.; Shan, H.; Xing, Y.H.; Shi, Z. Synthesis and characterization of novel transition metal complexes with indole acetic acid ligands: Evaluation of their catalytic activity for the oxidation of cyclohexane. Inorg. Chim. Acta 2014, 409, 360-366. [CrossRef]

21. Bilyachenko, A.N.; Yalymov, A.I.; Levitsky, M.M.; Korlyukov, A.A.; Es'kova, M.A.; Long, J.; Larionova, J.; Guari, Y.; Shul'pina, L.S.; Ikonnikov, N.S.; et al. First cage-like pentanuclear Co(II)-silsesquioxane. Dalton Trans. 2016, 45, 13663-13666. [CrossRef] [PubMed] 
22. Sun, B.; Yoshino, T.; Matsunaga, S.; Kanai, M. Air-Stable Carbonyl(pentamethylcyclopentadienyl)cobalt Diiodide Complex as a Precursor for Cationic (Pentamethylcyclopentadienyl)cobalt(III) Catalysis: Application for Directed C-2 Selective CH Amidation of Indoles. Adv. Synth. Catal. 2014, 356, 1491-1495. [CrossRef]

23. Gandeepan, P.; Cheng, C.-H. Cobalt Catalysis Involving $\pi$ Components in Organic Synthesis. Acc. Chem. Res. 2015, 48, 1194-1206. [CrossRef] [PubMed]

24. Reinig, R.R.; Mukherjee, D.; Weinstein, Z.B.; Xie, W.; Albright, T.; Baird, B.; Gray, T.S.; Ellern, A.; Miller, G.J.; Winter, G.J.; et al. Synthesis and Oxidation Catalysis of [Tris(oxazolinyl)borato]cobalt(II) Scorpionates. Eur. J. Inorg. Chem. 2016, 2486-2494. [CrossRef]

25. Fossey, J.; Lefort, D.; Massoudi, M.; Nedelec, J.-Y.; Sobra, J. Regiosélectivité et stéréosélectivité de l'hydroxylation homolytique des hydrocarbures par le peracide benzoïque. Can. J. Chem. 1985, 63, 678-680. [CrossRef]

26. Lindsay Smith, J.R.; Shul'pin, G.B. Efficient stereoselective oxygenation of alkanes by peroxyacetic acid or hydrogen peroxide and acetic acid catalysed by a manganese(IV) 1,4,7-trimethyl-1,4,7-triazacyclononane complex. Tetrahedron Lett. 1998, 39, 4909-4912. [CrossRef]

27. Shul'pin, G.B.; Lindsay-Smith, J.R. Oxidations by the reagent " $\mathrm{H}_{2} \mathrm{O}_{2}$-Manganese(IV) complex-Carboxylic acid". Part 1. Oxidation of saturated hydrocarbons with peroxy acids and hydrogen peroxide. Russ. Chem. Bull. 1998, 47, 2379-2386. [CrossRef]

28. Shul'pin, G.B.; Stoeckli-Evans, H.; Mandelli, D.; Kozlov, Y.N.; Tesouro Vallina, A.; Woitiski, C.B.; Jimenez, R.S.; Carvalho, W.A. Oxidation of alkanes with $m$-chloroperbenzoic acid catalyzed by iron(III) chloride and a polydentate amine. J. Mol. Catal. A Chem. 2004, 219, 255-264. [CrossRef]

29. Shul'pina, L.S.; Kudinov, A.R.; Süss-Fink, G.; Loginov, D.A.; Shul'pin, G.B. Oxidation of saturated hydrocarbons with peroxides catalyzed by iridium and palladium complexes. Pet. Chem. 2005, 45, 309-311.

30. Nagataki, T.; Tachi, Y.; Itoh, S. Ni ${ }^{\mathrm{II}}$ (TPA) as an efficient catalyst for alkane hydroxylation with $m$-CPBA. Chem. Commun. 2006, 4016-4018. [CrossRef] [PubMed]

31. Nagataki, T.; Itoh, S. Catalytic alkane hydroxylation reaction with nickel(II) complexes supported by di- and triphenol ligands. Chem. Lett. 2007, 36, 748-749. [CrossRef]

32. Ray, K.; Lee, S.M.; Que, L., Jr. Iron-oxidation-state-dependent O-O bond cleavage of MCPBA to form an iron(IV)-oxo complex. Inorg. Chim. Acta 2008, 361, 1066-1069. [CrossRef] [PubMed]

33. Nagataki, T.; Ishii, K.; Tachi, Y.; Itoh, S. Ligand effects on $\mathrm{Ni}^{\mathrm{II}}$-catalysed alkane-hydroxylation with $m$-CPBA. Dalton Trans. 2007, 1120-1128. [CrossRef] [PubMed]

34. Kamijo, S.; Amaoka, Y.; Inoue, M. Unified Oxidation Protocol for the Synthesis of Carbonyl Compounds Using a Manganese Catalyst. Synthesis 2010, 2475-2489.

35. Balamurugan, M.; Mayilmurugan, R.; Suresh, E.; Palaniandavar, M. Nickel(II) complexes of tripodal 4N ligands as catalysts for alkane oxidation using $m$-CPBA as oxidant: Ligand stereoelectronic effects on catalysis. Dalton Trans. 2011, 40, 9413-9424. [CrossRef] [PubMed]

36. Kikunaga, T.; Matsumoto, T.; Ohta, T.; Nakai, H.; Naruta, Y.; Ahn, K.-H.; Watanabe, Y.; Ogo, S. Isolation of a $\mathrm{Mn}^{\mathrm{IV}}$ acylperoxo complex and its monooxidation ability. Chem. Commun. 2013, 49, 8356-8358. [CrossRef] [PubMed]

37. Hikichi, S.; Hanaue, K.; Fujimura, T.; Okuda, H.; Nakazawa, J.; Ohzu, Y.; Kobayashi, C.; Akita, M. Characterization of nickel(II)-acylperoxo species relevant to catalytic alkane hydroxylation by nickel complex with $m$ CPBA. Dalton Trans. 2013, 42, 3346-3356. [CrossRef] [PubMed]

38. Nakazawa, J.; Yata, A.; Hori, T.; Stack, T.D.P.; Naruta, Y.; Hikichi, S. Catalytic Alkane Oxidation by Homogeneous and Siica-supported Cobalt(III) Complex Catalysts with a Triazolyl Group-containing Tetradentate Ligand. Chem. Lett. 2013, 42, 1197-1199. [CrossRef]

39. Nakazawa, J.; Hori, T.; Stack, T.D.P.; Hikichi, S. Alkane Oxidation by an Immobilized Nickel Complex Catalyst: Structural and Reactivity Differences Induced by Surface-Ligand Density on Mesoporous Silica. Chem. Asian J. 2013, 8, 1191-1199. [CrossRef] [PubMed]

40. Silva, T.F.S.; Mac leod, T.C.O.; Martins, L.M.D.R.S.; Guedes da Silva, M.F.C.; Schiavon, M.A.; Pombeiro, A.J.L. Pyrazole or tris(pyrazolyl)ethanol oxo-vanadium(IV) complexes as homogeneous or supported catalysts for oxidation of cyclohexane under mild conditions. J. Mol. Catal. A Chem. 2013, 367, 52-60. [CrossRef]

41. Hussain, H.; Al-Harrasi, A.; Gree, I.R.; Ahmed, I.; Abbas, G.; Rehman, N.U. meta-Chloroperbenzoic acid (mCPBA): A versatile reagent in organic synthesis. RSC Adv. 2014, 4, 12882-12917. [CrossRef] 
42. Sankaralingam, M.; Balamurugan, M.; Palaniandavar, M.; Vadivelu, P.; Suresh, C.H. Nickel(II) complexes of pentadentate N5 ligands as catalysts for alkane hydroxylation by using $m$-CPBA as oxidant: A combined experimental and computational study. Chem. Eur. J. 2014, 20, 11346-11361. [CrossRef] [PubMed]

43. Bilyachenko, A.N.; Yalymov, A.I.; Shul'pina, L.S.; Mandelli, D.; Korlyukov, A.A.; Vologzhanina, A.V.; Es'kova, M.A.; Shubina, E.S.; Levitsky, M.M.; Shul'pin, G.B. Novel Cage-Like Hexanuclear Nickel(II) Silsesquioxane. Synthesis, Structure, and Catalytic Activity in Oxidations with Peroxides. Molecules 2016, 21, 665. [CrossRef] [PubMed]

44. Shul'pin, G.B.; Nesterov, D.S.; Shul'pina, L.S.; Pombeiro, A.J.L. A hydroperoxo-rebound mechanism of alkane oxidation with hydrogen peroxide catalyzed by binuclear manganese (IV) complex in the presence of an acid with involvement of atmospheric dioxygen. Inorg. Chim. Acta 2016. [CrossRef]

45. Badiei, Y.M.; Wang, W.-H.; Hull, J.F.; Szalda, D.J.; Muckerman, J.T.; Himeda, Y.; Fujita, E. Cp*Co(III) catalysts with proton-responsive ligands for carbon dioxide hydrogenation in aqueous media. Inorg. Chem. 2013, 52, 12576-12586. [CrossRef] [PubMed]

46. Shul'pin, G.B.; Druzhinina, A.N. Hydroperoxidation of alkanes by atmospheric oxygen in the presence of hydroquinone or quinone catalyzed by copper(II) acetate under visible light irradiation. React. Kinet. Catal. Lett. 1992, 47, 207-211. [CrossRef]

47. Shul'pin, G.B.; Nizova, G.V. Formation of alkyl peroxides in oxidation of alkanes by $\mathrm{H}_{2} \mathrm{O}_{2}$ catalyzed by transition metal complexes. React. Kinet. Catal. Lett. 1992, 48, 333-338. [CrossRef]

48. Shul'pin, G.B. Metal-catalysed hydrocarbon oxygenations in solutions: The dramatic role of additives: A review. J. Mol. Catal. A Chem. 2002, 189, 39-66. [CrossRef]

49. Shul'pin, G.B. Metal-catalysed hydrocarbon oxidations. C. R. Chim. 2003, 6, 163-178. [CrossRef]

50. Shul'pin, G.B. Hydrocarbon Oxygenations with Peroxides Catalyzed by Metal Compounds. Mini-Rev. Org. Chem. 2009, 6, 95-104. [CrossRef]

51. Shul'pin, G.B.; Kozlov, Y.N.; Shul'pina, L.S.; Kudinov, A.R.; Mandelli, D. Extremely Efficient Alkane Oxidation by a New Catalytic Reagent $\mathrm{H}_{2} \mathrm{O}_{2} / \mathrm{Os}_{3}(\mathrm{CO})_{12}$ /Pyridine. Inorg. Chem. 2009, 48, 10480-10482. [CrossRef] [PubMed]

52. Shul'pin, G.B.; Kozlov, Y.N.; Shul'pina, L.S.; Petrovskiy, P.V. Oxidation of alkanes and alcohols with hydrogen peroxide catalyzed by complex $\mathrm{Os}_{3}(\mathrm{CO})_{10}(\mu-\mathrm{H})_{2}$. Appl. Organomet. Chem. 2010, 24, 464-472. [CrossRef]

53. Shul'pin, G.B. Selectivity enhancement in functionalization of $\mathrm{C}-\mathrm{H}$ bonds: A review. Org. Biomol. Chem. 2010, 8, 4217-4228. [CrossRef] [PubMed]

54. Shul'pin, G.B. C-H functionalization: Thoroughly tuning ligands at a metal ion, a chemist can greatly enhance catalyst's activity and selectivity. Perspective. Dalton Trans. 2013, 42, 12794-12818. [CrossRef] [PubMed]

55. Shul'pin, G.B. New Trends in Oxidative Functionalization of Carbon-Hydrogen Bonds: A Review. Catalysts 2016, 6, 50. [CrossRef]

56. Olivo, G.; Lanzalunga, O.; di Stefano, S. Non-Heme Imine-Based Iron Complexes as Catalysts for Oxidative Processes. Adv. Synth. Catal. 2016, 358, 843-863. [CrossRef]

57. Hong, J.; Djernes, K.E.; Lee, I.; Hooley, R.J.; Zaera, F. Heterogeneous Catalyst for the Selective Oxidation of Unactivated Hydrocarbons Based on a Tethered Metal-Coordinated Cavitand. ACS Catal. 2013, 3, 2154-2157. [CrossRef]

58. Zhou, W.-J.; Wisshert, R.; Xue, K.; Zheng, Y.-T.; Albela, B.; Bonneviot, L.; Clacens, J.-M.; Dea Campo, F.; Pera-Titus, M.; Wu, P. Highly Selective Liquid-Phase Oxidation of Cyclohexane to KA Oil over Ti-MWW Catalyst: Evidence of Formation of Oxyl Radicals. ACS Catal. 2014, 4, 53-62. [CrossRef]

59. Mahdavi, V.; Hasheminasab, H.R. Liquid-phase efficient oxidation of cyclohexane over cobalt promoted VPO catalyst using tert-butylhydroperoxide. J. Taiwan Inst. Chem. Eng. 2015, 51, 53-62. [CrossRef]

60. Palomas, D.; Kalamaras, C.; Haycock, P.; White, A.J.P.; Hellgardst, K.; Horton, A.; Crimmin, M.R. Re-evaluating selectivity as a determining factor in peroxidative methane oxidation by multimetallic copper complexes. Catal. Sci. Technol. 2015, 5, 4108-4115. [CrossRef]

61. Wang, B.; Lee, Y.-M.; Clémancey, M.; Seo, M.S.; Sarangi, R.; Latour, J.-M.; Nam, W. Mononuclear Nonheme High-Spin Iron(III)-Acylperoxo Complexes in Olefin Epoxidation and Alkane Hydroxylation Reactions. J. Am. Chem. Soc. 2016, 138, 2426-2436. [CrossRef] [PubMed] 
62. Liu, T.; Cheng, H.; Sun, L.; Liang, F.; Zhang, C.; Ying, Z.; Lin, W.; Zhao, F. Synthesis of acetophenone from aerobic catalytic oxidation of ethylbenzene over Ti-Zr-Co alloy catalyst: Influence of annealing conditions. Appl. Catal. A Gen. 2016, 512, 9-14. [CrossRef]

63. Martins, L.M.D.R.S.; de Almeida, M.P.; Carabineiro, S.A.C.; Figueiredo, J.L.; Pombeiro, A.J.L. Heterogenisation of a C-Scorpionate $\mathrm{Fe}^{\mathrm{II}}$ Complex on Carbon Materials for Cyclohexane Oxidation with Hydrogen Peroxide. Chem CatChem 2013, 5, 3847-3856. [CrossRef]

64. Das, B.; Al-Hunaiti, A.; Haukka, M.; Demeshko, S.; Meyer, S.; Shteinman, A.A.; Meyer, F.; Repo, T.; Norlander, E. Catalytic Oxidation of Alkanes and Alkenes by $\mathrm{H}_{2} \mathrm{O}_{2}$ with a $\mu$-Oxido Diiron(III) Complex as Catalyst/Catalyst Precursor. Eur. J. Inorg. Chem. 2015, 3590-3601. [CrossRef]

65. Dias, S.S.P.; Kirillova, M.V.; André, V.; Kłak, J.; Kirillov, A.M. New tricopper(II) cores self-assembled fromaminoalcohol biobuffers and homophthalic acid: Synthesis, structural and topological features, magnetic properties and mild catalytic oxidation of cyclic and linear C5-C8 alkanes. Inorg. Chem. Front. 2015, 2, 525-537. [CrossRef]

66. Olivo, G.; Nardi, M.; Vìdal, D.; Barbieri, A.; Lapi, A.; Gómez, L.; Lanzalunga, O.; Costas, M.; di Stefano, S. C-H Bond Oxidation Catalyzed by an Imine-Based Iron Complex: A Mechanistic Insight. Inorg. Chem. 2015, 54, 10141-10152. [CrossRef] [PubMed]

67. Martins, L.; Nasani, R.; Saha, M.; Mobin, S.; Mukhopadhyay, S.; Pombeiro, A.J.L. Greener Selective Cycloalkane Oxidations with Hydrogen Peroxide Catalyzed by Copper-5-(4-pyridyl)tetrazolate Metal-Organic Frameworks. Molecules 2015, 20, 19203-19220. [CrossRef] [PubMed]

68. Ribeiro, A.P.C.; Martins, L.M.D.R.S.; Hazra, S.; Pombeiro, A.J.L. Catalytic oxidation of cyclohexane with hydrogen peroxide and a tetracopper(II) complex in an ionic liquid. C. R. Chim. 2015, 18, 758-765. [CrossRef]

69. Al-Hunaiti, A.; Räisänen, M.; Repo, T. From DNA to Catalysis: Thymine-acetate ligated non-heme iron(III) catalyst for oxidative activation of aliphatic C-H bonds. Chem. Commun. 2016, 52, 2043-2046. [CrossRef] [PubMed]

70. Szymańska, A.; Nitck, W.; Oszajaca, M.; Łasocha, W.; Pamin, K.; Pońtowicz, J. Molybdenum Complexes as Catalysts for the oxidation of Cycloalkanes with Molecular Oxygen. Catal. Lett. 2016, 146, 998-1010. [CrossRef]

71. Simaioforidou, A.; Papastergiou, M.; Margellou, A.; Petrakis, D.; Louloudi, M. Activated vs. Pyrolytic Carbon as Support Matrix for Chemical Functionalization: Efficient Heterogeneous non-Heme Mn(II) Catalysts for Alkene Oxidation with $\mathrm{H}_{2} \mathrm{O}_{2}$. J. Mol. Catal. A Chem. 2016. [CrossRef]

72. Zhan, B-Z.; Modén, B.; Dakka, J.; Santiesteban, J.G.; Iglesia, E. Catalytic oxidation of $n$-hexane on Mn-exchanged zeolites: Turnover rates, regioselectivity, and spatial constraints. J. Catal. 2007, 245, 316-325.

73. Aprile, C.; Corma, A.; Domine, M.E.; Garcia, H.; Mitchell, C. A cascade aerobic epoxidation of alkenes over $\mathrm{Au} / \mathrm{CeO}_{2}$ and Ti-mesoporous material by "in situ" formed peroxides. J. Catal. 2009, 264, 44-53. [CrossRef]

74. Mahmudov, K.T.; Kopylovich, M.N.; Guedes da Silva, M.F.C.; Figiel, P.J.; Karabach, Y.Y.; Pombeiro, A.J.L. New copper(II) dimer with 3-(2-hydroxy-4-nitrophenylhydrazo)pentane-2,4-dione and its catalytic activity in cyclohexane and benzyl alcohol oxidations. J. Mol. Catal. A Chem. 2010, 318, 44-50. [CrossRef]

75. Estrada, A.C.; Simões, M.M.Q.; Santos, I.C.M.S.; Graca, M.; Neves, P.M.S.; Cavaleiro, J.A.S.; Cavaleiro, A.M.V. Catalytic activity of iron-substituted polyoxotungstates in the oxidation of aromatic compounds with hydrogen peroxide. Monatsh. Chem. 2010, 141, 1223-1235. [CrossRef]

76. Jiang, D.; Mallat, T.; Meier, D.M.; Urakawa, A.; Baiker, A. Copper metal-organic framework: Structure and activity in the allylic oxidation of cyclohexene with molecular oxygen. J. Catal. 2010, 270, 26-33. [CrossRef]

77. Lloyd, R.; Jenkins, R.L.; Piccinini, M.; He, Q.; Kiely, C.J.; Carley, A.F.; Golunski, S.E.; Bethell, D.; Bartley, J.K.; Hutchings, G.J. Low-temperature aerobic oxidation of decane using an oxygen-free radical initiator. J. Catal. 2011, 283, 161-167. [CrossRef]

78. Maksimchuk, N.V.; Kolenko, K.A.; Fedin, V.P.; Kholdeeva, O.A. Cyclohexane selective oxidation over metal-organic frameworks of MIL-101 family: Superior catalytic activity and selectivity. Chem. Commun. 2012, 48, 6812-6814. [CrossRef] [PubMed]

79. Cao, Y.; Yu, H.; Peng, F.; Wang, H. Selective Allylic Oxidation of Cyclohexene Catalyzed by Nitrogen-Doped Carbon Nanotubes. ACS Catal. 2014, 4, 1617-1625. [CrossRef]

80. Garcia-Bosch, I.; Siegler, M.A. Copper-Catalyzed Oxidation of Alkanes with $\mathrm{H}_{2} \mathrm{O}_{2}$ under a Fenton-like Regime. Angew. Chem. Int. Ed. 2016, 55, 12873-12876. [CrossRef] [PubMed] 
81. Hazra, S.; Ribeiro, A.P.C.; Guedes da Silva, M.F.C.; de Castro, C.A.N.; Pombeiro, A.J.L. Syntheses and crystal structures of benzene-sulfonate and -carboxylate copper polymers and their application in the oxidation of cyclohexane in ionic liquid under mild conditions. Dalton Trans. 2016. [CrossRef]

82. Haslinger, S.; Raba, A.; Cokoja, M.; Pöthig, A.; Kühn, F.E. Iron-catalyzed oxidation of unreactive C-H bonds: Utilizing bio-inspired axial ligand modification to increase catalyst stability. J. Catal. 2015, 331, 147-153. [CrossRef]

83. Silva, T.F.S.; Rocha, B.G.M.; Guedes da Silva, M.F.C.; Martins, L.M.D.R.S.; Pombeiro, A.J.L. V(IV), Fe(II), $\mathrm{Ni}(\mathrm{II})$ and $\mathrm{Cu}(\mathrm{II})$ complexes bearing 2,2,2-tris(pyrazol-1-yl)ethyl methanesulfonate: Application as catalysts for the cyclooctane oxidation. New J. Chem. 2016, 40, 528-537. [CrossRef]

84. Gupta, S.; Kirillova, M.V.; Guedes da Silva, M.F.C.; Pombeiro, A.J.L.; Kirillov, A.M. Alkali Metal Directed Assembly of Heterometallic Vv/M (M = Na, K, Cs) Coordination Polymers: Structures, Topological Analysis, and Oxidation Catalytic Properties. Inorg. Chem. 2013, 52, 8601-8611. [CrossRef] [PubMed]

85. Naicker, D.; Friedrich, H.; Omondi, B. Cobalt aminodiphosphine complexes as catalysts in the oxidation of n-octane. RSC Adv. 2015, 5, 63123-63129. [CrossRef]

86. Xue, S.; Chen, G.; Long, Z.; Zhou, Y.; Wang, J. Efficient and recyclable multi-cationic polyoxometalate-based hybrid catalyst for heterogeneous cyclohexane oxidation with $\mathrm{H}_{2} \mathrm{O}_{2}$. RSC Adv. 2015, 5, 19306-19314. [CrossRef]

87. Wu, M.; Zhan, W.; Guo, Y.; Guo, Y.; Wang, Y.; Wang, L.; Lu, G. An effective Mn-Co mixed oxide catalyst for the solvent-free selective oxidation of cyclohexane with molecular oxygen. Appl. Catal. A: General 2016, 523, 97-106. [CrossRef]

88. Mncube, S.G.; Bala, M.D. Recoverable aqueous-ionic liquid biphasic catalyst system for the oxidation of n-octane. J. Mol. Liq. 2016, 215, 396-401. [CrossRef]

89. Dias, S.S.P.; Kirillova, M.V.; André, V.; Klak, J.; Kirillov, A.M. New Tetracopper(II) Cubane Cores Driven by a Diamino Alcohol: Selfassembly Synthesis, Structural and Topological Features, and Magnetic and Catalytic Oxidation Properties. Inorg. Chem. 2015, 54, 5204-5212. [CrossRef] [PubMed]

90. Sutradhar, M.; Martins, L.M.D.R.S.; Guedes da Silva, M.F.C.; Mahmudov, K.T.; Liu, C.-M.; Pombeiro, A.J.L. Trinuclear $\mathrm{Cu}^{\mathrm{II}}$ Structural Isomers: Coordination, Magnetism, Electrochemistry and Catalytic Activity towards the Oxidation of Alkanes. Eur. J. Inorg. Chem. 2015, 3959-3969. [CrossRef]

91. Fernandes, T.A.; Santos, C.I.M.; André, V.; Dias, S.S.P.; Kirillova, M.V.; Kirillov, A.M. New aqua-soluble dicopper(II) aminoalcoholate cores for mild and water-assisted catalytic oxidation of alkanes. Catal. Sci. Technol. 2016, 6, 4584-4593. [CrossRef]

92. Vikse, K.L.; Ahmadi, Z.; McIndoe, J.S. The application of electrospray ionization mass spectrometry to homogeneous catalysis. Coord. Chem. Rev. 2014, 279, 96-114. [CrossRef]

93. Mutseneck, E.V.; Loginov, D.A.; Perekalin, D.S.; Starikova, Z.A.; Golovanov, D.G.; Petrovskii, P.V.; Zanello, P.; Corsini, M.; Laschi, F.; Kudinov, A.R. (Tetramethylcyclobutadiene)cobalt Complexes with Five-Electron Carbo- and Heterocyclic Ligands. Organometallics 2004, 23, 5944-5957. [CrossRef]

94. Kudinov, A.R.; Mutseneck, E.V.; Loginov, D.A. (Tetramethylcyclobutadiene)cobalt chemistry. Coord. Chem. Rev. 2004, 248, 571-585. [CrossRef]

95. King, R.B. Organometallic chemistry of the transition metals. XI. Some new cyclopentadienyl derivatives of cobalt and rhodium. Inorg. Chem. 1966, 5, 82-87. [CrossRef]

96. Kudinov, A.R.; Loginov, D.A.; Muratov, D.V.; Petrovskii, P.V. Synthesis of dicationic triple-decker complexes with a central B-cyclohexyl-substituted borole ligand. Russ. Chem. Bull. 2001, 50, 1332-1333. [CrossRef]

97. Roe, D.M.; Maitlis, P.M. Disproportionation of Dihalogenocyclopentadienylcobalt Complexes to Cobaltocenium Salts. J. Chem. Soc. A 1971, 3173-3175. [CrossRef]

98. Sheldrick, G.M. A short history of SHELX. Acta Cryst. 2008, A64, 112-122. [CrossRef] [PubMed]

Sample Availability: Samples of the compounds 1-10 are available from the authors. 